\title{
Late Quaternary paleoenvironmental reconstruction and paleoclimatic implications of the Aegean Sea (eastern Mediterranean) based on paleoceanographic indexes and stable isotopes
}

\author{
G. Kontakiotis \\ National and Kapodistrian University of Athens, School of Earth Science, Faculty of Geology and Geoenvironment, Department of Historical Geology- \\ Paleontology, Panepistimiopolis, Zografou, 15784, Greece
}

\section{A R T I C L E I N F O}

\section{Article history:}

Available online xxx

\section{Keywords:}

Palaeoceanography

Palaeoenvironmental reconstruction

SST

Productivity

Water column stratification

Seasonality

\begin{abstract}
A B S T R A C T
The Late Quaternary palaeoenvironmental evolution and the main palaeoceanographic changes of the Aegean Sea was reconstructed using planktonic foraminifera obtained from the sediments of a northern (SK-1) and a southern (NS-14) core site. Multivariate statistical approach, including Q-mode cluster and Principal Component (PCA) Analyses, gives an insight into the relationships between sea surface environmental changes between the north and south Aegean, and furthermore serves as a baseline data set for palaeoclimatic and palaeoceanographic reconstructions of the eastern Mediterranean Sea. Stable isotope analyses coupled with additional paleoceanographic (sea surface temperature (SST), productivity (SSP), stratification (S-index), upwelling (U-index), seasonality (Sn-index)) proxies provide insights into the sedimentological, hydrographic and trophic evolution and ecosystem dynamics of the Aegean Sea, and furthermore serve as a baseline data set for palaeoclimatic and palaeoceanographic reconstructions of the eastern Mediterranean Sea. Concentrating on the last $19 \mathrm{ka}$, faunal and isotopic data concur, suggesting a series of climatic zones, corresponding to well-known climatic phases of the last glacial cycle. Cold and arid conditions during the late glacial period were followed by a warmer and wetter climate trend during deglacial time. A marked seasonality, characterized by homogenous water column favored by efficient upwelling during the winter and by warm stratified water column during the summer, has also been recognized during this period (Bølling-Allerød - B-A) in both basins. An abrupt switch to cool, arid climatic event (Younger Dryas - YD) suggests a strengthening of winter convection around $12.9 \mathrm{ka}$, which seems to be more evident in the north Aegean core. However, the more pronounced environmental changes between the north and south Aegean Sea were identified during the Holocene, and they coincide with the deposition of sapropel S1 and Sapropel-Mid-Holocene (SMH). The comparison between SK-1 and NS-14 records indicated significant changes in both the productivity and stratification patterns, with the former the main factor in north Aegean and the latter in south Aegean for S1 deposition. Regarding the localized deposition of SMH in the semi-enclosed shallow south Aegean site, the fully oxygenated and less productive water column conditions prevailing during that time (5.4 $-4.3 \mathrm{ka}$ ) in the north Aegean were the limiting factor for its deposition.
\end{abstract}

(๑) 2015 Elsevier Ltd and INQUA. All rights reserved.

\section{Introduction}

The Eastern Mediterranean Sea has been the focus of intensive studies during the last half-century. The crucial importance of this small marginal basin lies in its capability to register and amplify the smallest climatic variations occurring in the mid-latitude regions (Marino et al., 2007, 2009). The signals registered by changes in

E-mail address: gkontak@geol.uoa.gr. abundance and distribution of fossil micro-organisms, such as planktonic foraminifera, represent one of the most powerful tools for environmental reconstruction. In this study area, they provide a reliable and well-documented record at both global and local scales. Planktonic foraminifera are reliable indicators of sea surface temperature (SST), sea surface salinity (SSS), food availability and in general changes in the state of the prevailing hydrographic systems in the water column (Pujol and Vergnaud-Grazzini, 1995); and they have been used for the detection of long- and short-duration palaeoclimatic and palaeoceanographic changes in the study area 
during the Quaternary (Geraga et al., 2000, 2005, 2010; Marino et al., 2007, 2009; Triantaphyllou et al., 2009a,b, 2010). They can be viewed as "fingerprints" of the water masses that they occupy, behaving as indicators of temperature, salinity, and nutrient content, yielding indirect information on climate-related parameters.

In the eastern Mediterranean, accumulation rates are generally low with the exception of the Aegean Sea, an area with unusually high sedimentation rates where a large number of high quality gravity cores have been recovered. The higher sedimentation rates reported for the marginal basin of the Aegean Sea (e.g. Zachariasse et al., 1997; Geraga et al., 2000, 2005; Casford et al., 2007; Triantaphyllou et al., 2009a,b; Drinia et al., 2014) compared to the more oceanic sites of the Mediterranean Sea, in conjunction with the remoteness of this basin from the foci of monsoon-sourced freshwater injections during intervals of sapropel deposition (Rohling et al., 2002) allow detailed records of change to be preserved, and facilitate the assessment of basin-integrated paleoceanographic responses. Given that the Aegean Sea is one of the most oligotrophic areas of the global ocean system (Ignatiades et al., 2002), much interest is centered on the north and south Aegean sub-basins, because they present a clear southern trend towards an oligotrophy gradient, expressed in all biochemical parameters of the euphotic zone (Lykousis et al., 2002). This differential response of the biological and chemical processes taking place in the Aegean water column is also affected by environmental changes (e.g. local freshwater inputs and the role of physiography in the distribution of temperature and precipitation) and thereby is expressed differently in sediment records from the various subbasins. The combination of all the above controlling factors creates within the Aegean Sea a $(\mathrm{N}-\mathrm{S}$ trending) complex system regarding its hydrology, water masses circulation, biological, chemical, and sedimentological processes.

Attention is focused on the planktonic foraminifera retrieved from the Aegean Sea, which contribute to palaeoenvironmental reconstruction of the last glacial cycle (Termination I, T1). The purpose of this study is to identify and describe the distributional patterns of late Quaternary planktonic foraminifera from the north and south Aegean, and to speculate on their relations to palaeoceanographic and palaeoclimatic conditions. This is rather important as there is still too little information available on hydrographic changes (comparative observations in terms of surface water stratification, fertilization and seasonal climatic and oceanographic contrasts) that occurred in such an important region that is considered today to be the main source area of new deep water formation for the open eastern Mediterranean (Roether et al., 1996), consequently supplying oxygen to the deep sea and playing a crucial role in the functioning of the thermohaline circulation of the entire Mediterranean basin (Theocharis et al., 1999). In order to better understand the hydrographic and productivity variations and the inter-relations and interactions between the sub-basins, two high-sedimentation rate cores from the north (SK-1) and south (NS-14) sub-basins respectively were investigated. Special attention is given to SST and export productivity variations across $\mathrm{T} 1$ and during the deposition of the most recent sapropel S1.

\section{Oceanographic setting}

The Aegean Sea is in the northern sector of the eastern Mediterranean, between the Turkish coastline to the east, the Greek mainland to the north and west, and bounded on the south by the island of Crete. It communicates with the Black Sea through the Straits of Bosporus and Dardanelles, and with the open eastern Mediterranean (Levantine Sea) through several larger and deeper straits between Peloponnesus, the islands of Crete and Rhodes and south-western Turkey (Fig. 1). It is separated into two main sub- basins, the north and the south Aegean, with significantly different hydrographic characteristics (Lykousis et al., 2002), which are controlled by the exchange of water masses with the Levantine and Black Seas and by the climate contrasts between more humid conditions in the north and semi-arid conditions in the south. It is characterised, in general, by a cyclonic water circulation, although the most active dynamic features are the mesoscale cyclonic and anticyclonic eddies, either permanent and/or recurrent (Lykousis et al., 2002). In the north Aegean, antagonistic influences of freshwater influx from the Black Sea and surrounding rivers (Zervakis et al., 2000) on the one hand, and winter cooling on the other, determine the extent to which this basin supplies dense deep water and oxygen to the whole Mediterranean. In contrast, the south Aegean is one of the most oligotrophic areas in the Mediterranean Sea (Lykousis et al., 2002), with its surface water circulation mostly affected by arid climatic conditions, while it is also modulated by the effect of the Cretan gyre (Lykousis, 2001). Additionally, on a seasonal time-scale, there is a major change in the Aegean Sea circulation pattern, which may be playing a significant role, not only in influencing its longer-term hydrographic properties, but also in affecting its ecosystem (Zervakis et al., 2005). This seasonal change that takes place annually in the Aegean Sea is the coastal upwelling of intermediate waters, evident every summer along the eastern Aegean, as a response to the persistence of the Etesian northerly winds during the summer period (Poulos et al., 1997).

\section{Materials and methods}

\subsection{Study sites}

Two gravity cores (NS-14 and SK-1) along the Aegean Sea were used in the present study (Fig. 1). Core SK-1 was recovered during the $1982 \mathrm{R} / \mathrm{V}$ Discovery cruise in the north Aegean Basin (Skopelos basin; $38^{\circ} 80^{\prime} \mathrm{N}$ and $23^{\circ} 80^{\prime} \mathrm{E}$; $1000 \mathrm{~m}$ water depth, length $800 \mathrm{~cm}$ ) and covers the last $19 \mathrm{ka}$. Skopelos basin is located in the southern part of the north Aegean Sea (Papanikolaou et al., 2002) and is characterized by the "continental margin" sedimentation processes of the north Aegean (Lykousis et al., 2002; Poulos, 2009). Core NS14 was recovered during the $1998 \mathrm{R} / \mathrm{V}$ Aegaeo cruise, from a shallower site, at the easternmost edge of the recent Aegean volcanic arc in south Aegean Sea (western Kos basin; $36^{\circ} 38^{\prime} \mathrm{N}$ and $27^{\circ} 00^{\prime} \mathrm{E}$; $505 \mathrm{~m}$ water depth, length $400 \mathrm{~cm}$ ) and comprises the last $\sim 13 \mathrm{ka}$. Detailed descriptions of the studied cores are given in Triantaphyllou et al. (2009a,b) and Zachariasse et al. (1997) respectively. Both cores contain distinct organic-rich dark intervals representing the regional expression of the most recent sapropel S1 (Casford et al., 2002, 2003; Rohling et al., 2002) (Fig. 2A,B). In contrast to the core-SK-1, the S1 layer in NS-14 is divided into two sub-units ( $\mathrm{S} 1 \mathrm{a}$ and $\mathrm{S} 1 \mathrm{~b}$ ) separated by a lightcolored interval, which corresponds to the S1 interruption (S1i) (Fig. 2A). Detailed investigations of the $\mathrm{S} 1$ occurrence in these cores have been reported earlier (Casford et al., 2007; Kontakiotis et al., 2009, 2013; Triantaphyllou et al., 2009a,b; Kontakiotis, 2012; Kouli et al., 2012). In NS-14, the most recent Z2 Santorini ash layer is positioned at $17 \mathrm{~cm}$ depth, and a sapropel-like, dark olive grey mud layer (Sapropel Mid Holocene - SMH) is deposited between 25 and $40 \mathrm{~cm}$ (Triantaphyllou et al., 2009a,b; 2013) (Fig. 2A).

\subsection{Time stratigraphic framework}

The chronostratigraphy of the cores studied is based on 7 previously published accelerator mass spectroscopy radiocarbon (AMS ${ }^{14} \mathrm{C}$ ) dates available for NS-14 and four for core SK-1, supplemented by the additional dating of the time marker correlative to the 


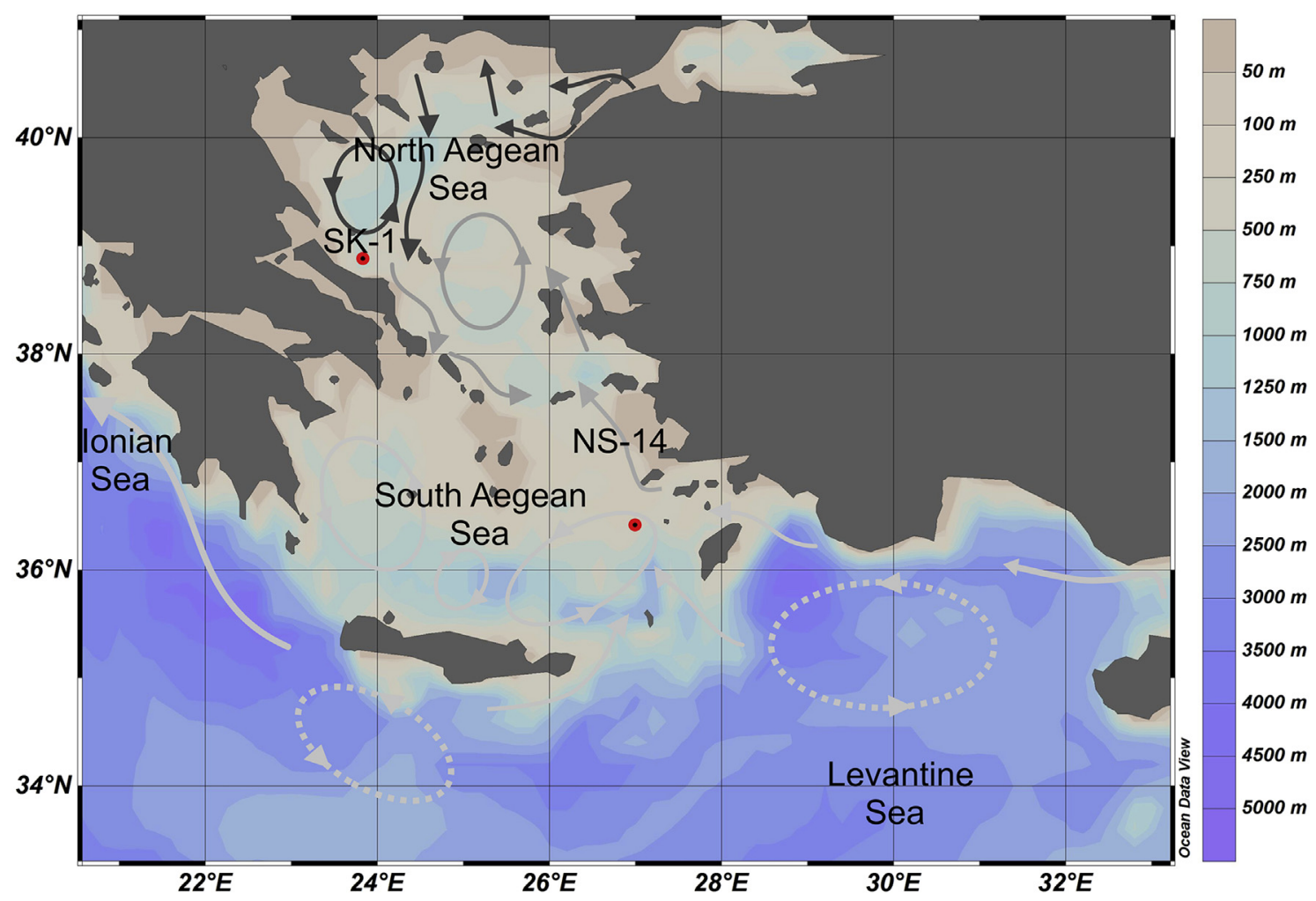

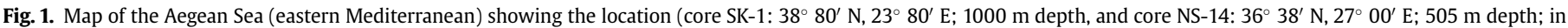
red) of the analyzed sediment cores. For interpretation of the references to color in this figure legend, the reader is referred to the web version of this article.

Minoan eruption of Santorini in NS-14 (Zachariasse et al., 1997; Triantaphyllou et al., 2009a,b). For the age model of SK-1 core, bio-stratigraphic control also provides two well-dated correlation horizons, the biozone I/II and II/III boundaries of Jorissen et al. (1993), which are useful chronologic standards for dating late Quaternary sequences in the central and eastern Mediterranean (including the Aegean Sea - Zachariasse et al., 1997; Casford et al., 2002; Geraga et al., 2010) due to their Mediterranean-wide applicability and synchroneity (Capotondi et al., 1999; Hayes et al., 1999; Casford et al., 2001). Both age models previously published by Triantaphyllou et al. (2009b) and Casford et al. (2007) respectively have been tested against the multi-proxy chronological framework proposed by Casford et al. (2007) for a generous number of sediment cores from the Aegean Sea. The ages in this study are given in calibrated ka BP.

\subsection{Micropalaeontological processing and multivariate statistical analyses}

For planktonic foraminiferal analysis, the preparation of 116 samples (67 from NS-14 and 49 from SK-1) followed the standard micropaleontological techniques. For detailed descriptions of the quantitative methods and taxonomy, refer to Hemleben et al. (1989). Results of quantitative analysis were processed using PAST (1.19) multivariate statistical software package of Hammer et al. (2001), after exclusion of rare species (<3\%). Q-mode cluster analysis was used to determine the overall statistical similarity between samples, following the algorithms of Davis (1973) using the correlation coefficient matrix. The results of cluster analysis were reported as Euclidean distances and arranged in two-dimensional hierarchical dendrograms, wherein locations were presented along the Y-axis while similarity level is plotted on the X-axis. Principal Component Analyses (PCA) is used to reduce the dimensionality of a multivariate data set to a few principal factors that determine the distributions of species. The resulting factor scores show the contribution of each factor in every sample and therefore the down-core contribution of each factor. The total number of factors was defined by minimizing the remaining "random" variability and by the possibility to relate the factors to modern hydrographic conditions and planktonic foraminiferal ecology.

\subsection{Stable isotope analyses}

Sediment samples from NS-14 core were dried overnight at $50{ }^{\circ} \mathrm{C}$, then weighed and disaggregated in ultra clean water for $6 \mathrm{~h}$ on a shaker table. To collect the coarse fraction, samples were wetsieved using a $63 \mu \mathrm{m}$ mesh. For stable oxygen and carbon isotope measurements $\left(\delta^{18} \mathrm{O}, \delta^{13} \mathrm{C}\right), 20-30$ specimens of the planktonic species Globigerinoides ruber $(\mathrm{w})$ were picked from the 250-350 $\mu \mathrm{m}$ size fraction. This size fraction limitation was used to minimize ontogenetic and growth rate effects on shell geochemistry (Spero et al., 2003). Isotopic analyses of G. ruber shells were performed using an automated individual acid bath carbonate preparation device (KIEL II), coupled to a dual-inlet isotope mass spectrometer (Finnigan MAT253) at Utrecht University. Foraminiferal $\delta^{18} \mathrm{O}$ and $\delta^{13} \mathrm{C}$ data were calibrated to National Bureau of Standards-19 (NBS19), and the isotope values are reported in \%o relative to Vienna Peedee Belemnite (VPDB) scale. The external standard errors of the stable carbon and oxygen isotope analyses are $<0.06$ and $0.08 \%$ respectively.

\subsection{Sea surface temperature (SST), productivity, stratification and seasonality proxies}

The absolute calibration of faunal SST proxies in the Mediterranean Sea is problematic because of the different factors other 


\section{Core NS-14 (South Aegean)}

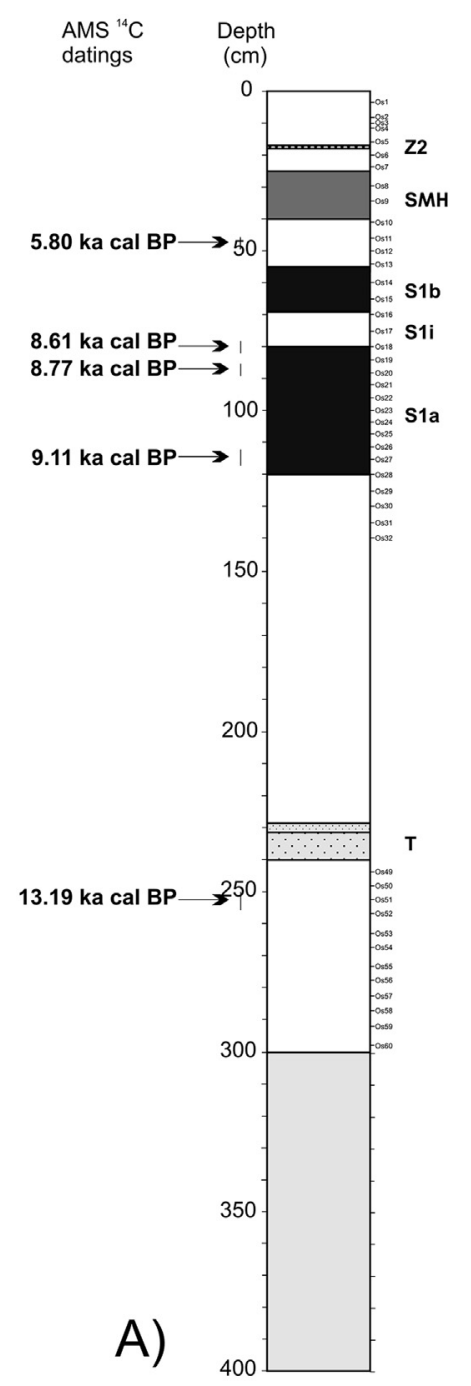

\section{Core SK-1 (North Aegean)}

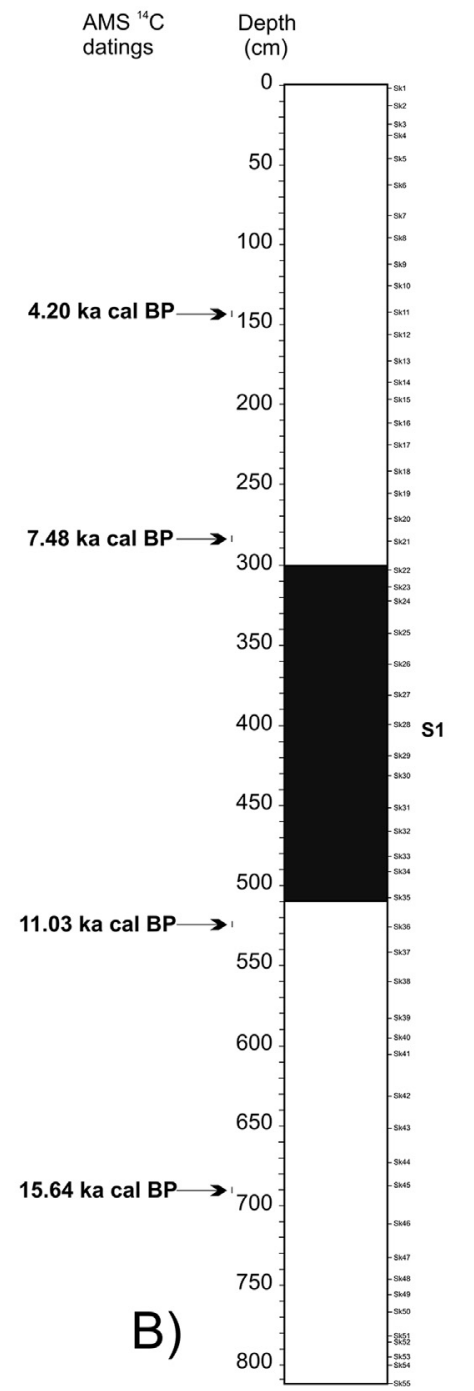

\section{Legend}

\author{
Z2: Santorini ash layer Z-2 \\ S1b: Upper lobe of S1 \\ S1i: $\quad$ 1 interruption interval \\ S1a: Lower lobe of S1 \\ T: Turbiditic layer \\ Mass gravity flow event \\ Sapropel S1 \\ Sapropel Mid Holocene (SMH) \\ Turbidite
}

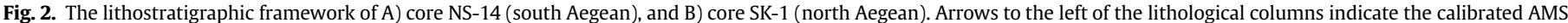
${ }^{14} \mathrm{C}$ datings. In the right of the plots of lithology versus depth, the sampling intervals are also displayed. Depth is in centimeters (cm).

than temperature influencing the distribution of planktonic foraminiferal species (mainly food availability). However, the planktonic foraminiferal relative distributions are used as a first-order estimate of SST variations. An index of the SST variations was constructed based on the down-core variation of planktonic foraminiferal abundances, and it was referred to as Planktonic Paleoclimatic Curve (PPC). The PPC was obtained by the formula $(\mathrm{w}-\mathrm{c})^{*} 100 /(\mathrm{w}+\mathrm{c})$, where $w$ represents the warm-water indicators and $c$ the cold water indicators (Rohling et al., 1993). They are a good example of the robustness of biological proxies as paleoenvironmental indicators and closely reflect the trend shown by the G. ruber $\delta^{18} \mathrm{O}$ records which also used here to infer SST variations. Stable oxygen isotopes are used to highlight the correspondence with the faunal profiles to estimate the extent and intensity of each climatic perturbation. The \% percentage of Globigerina bulloides was estimated as an upwelling index (U-index), since its flourishing is attributed to elevated food levels due to coastal upwelling phenomena (Hemleben et al., 1989). Moreover, the down-core G. ruber $\delta^{13} \mathrm{C}$ record (core NS-14) and the ratio of eutrophic to oligotrophic species (E-index; core SK-1) can also be used to infer sea surface productivity (SSP) variations. The Eutrophication index (E-index) was estimated using the sum of the eutrophic (Neogloboquadrina pachyderma, Neogloboquadrina dutertrei, Globigerina bulloides, Turborotalita quinqueloba, Globorotalia inflata) species versus the sum of the eutrophic plus oligotrophic (Globigerinoides ruber alba, Globigerinoides ruber rosea, Globoturborotalita rubescens, Globigerinoides sacculifer, Orbulina universa, Globigerina siphonifera) species. The down-core ratio between $G$. bulloides and G. ruber was also estimated showing the degree of the stratification of the upper water column (Sbaffi et al., 2004). This ratio, referred here as S-index, is an index of oceanographic conditions showing periods of strong summer stratification of the water column where oligotrophic taxa dominate (low values) and periods of strong winter mixing of the water column 
where eutrophic taxa dominate (high values). Finally, the \% percentage of Globigerinita glutinata was estimated as a seasonality index, since this species can survive in both oligotrophic surface and eutrophic deeper waters (Hemleben et al., 1989; Schiebel and Hemleben, 2000; Schiebel et al., 2001). This dual behavior of this species is primarily due to its diet requirements (diatoms versus chrysophytes), which vary from season to season (Hemleben et al., 1989).

\section{Results}

\subsection{Q-mode cluster analysis}

Four and three distinct assemblages of planktonic foraminifera were identified by Q-mode cluster analysis in the south and north Aegean respectively, reflecting different assemblages during the Late Quaternary (Figs. 3 and 4). Each assemblage is characterized by and named for the dominant species as follows.

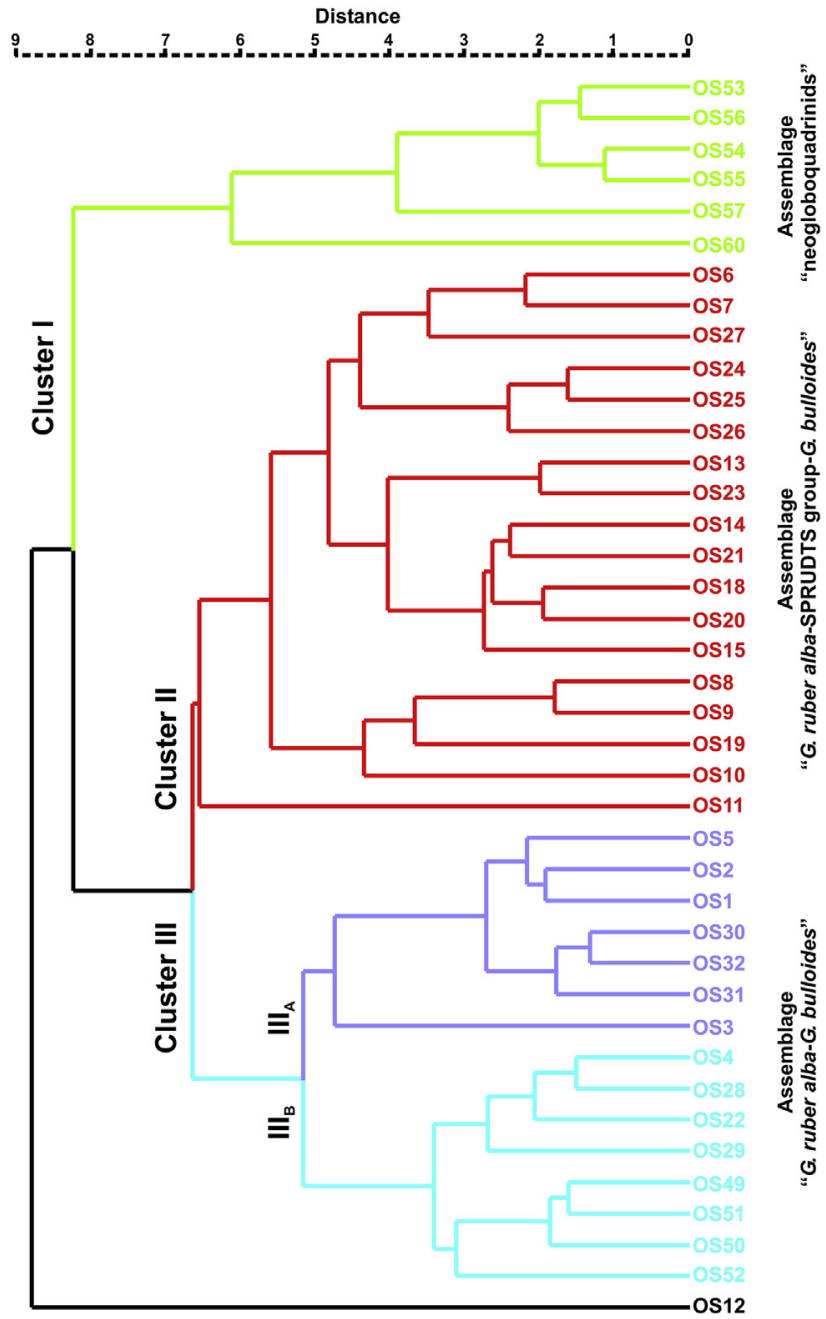

Fig. 3. Dendrogram resulting from Q-mode cluster analysis and the clusters identified in core NS-14 (south Aegean). In the right of the plot, the relevant assemblages (" $G$. ruber alba-G. bulloides" assemblage in light purple (Cluster $\mathrm{III}_{\mathrm{A}}$ ) and cyan (Cluster $\mathrm{III}_{\mathrm{B}}$ ), "G. ruber alba-SPRUDTS group-G. bulloides" assemblage in red (Cluster II), and "neogloboquadrinids" assemblage in light green (Cluster I) color are also shown. For interpretation of the references to color in this figure legend, the reader is referred to the web version of this article.

\subsubsection{South Aegean}

4.1.1.1. Cluster I (assemblage neogloboquadriniids). It contains 6 samples (OS53-OS57, OS60) and represents the lower part $(263-300 \mathrm{~cm})$ of core NS-14 corresponding to the T1. This assemblage is dominated by neogloboquadriniids. Besides the key species ( $N$. dutertrei or N. pachyderma) of this assemblage, many species occurred abundantly, such as G. glutinata, G. bulloides and G. ruber indicating the existence of eutrophic, low-salinity, well-stratified environment (Vergnaud Grazzini et al., 1977; Rohling et al., 1993; Zachariasse et al., 1997; Geraga et al., 2010). The latter consists of the formation of a well-developed Deep Chlorophyll Maximum (DCM) layer, in which enhanced production can be realized by shoaling of the thermocline to a depth that falls well within the euphotic layer.

4.1.1.2. Cluster II (assemblage G. ruber alba-SPRUDTS group-G. bulloides). It contains 18 samples (OS6-OS11, OS13-OS21 and OS23-OS27) representing mainly the deposition of sapropel S1. This assemblage is mainly dominated by species representative of warm and oligotrophic waters (G. ruber alba, G. ruber rosea, G. sacculifer, G. siphonifera, and $O$. universa), and shows a significant increase in the relative percentages of G. bulloides, compared to Cluster I. The latter is indicative of a relatively mesotrophic to eutrophic environment during the deposition of $\mathrm{S} 1$, and could be attributed to the increased riverine inputs in the surficial waters (Rohling et al., 1997; Zachariasse et al., 1997; Geraga et al., 2005, 2008, 2010).

4.1.1.3. Cluster III (assemblage G. ruber alba-G. bulloides). It contains 16 samples (OS1-OS5, OS22, OS28-OS32 and OS49-OS52) and subdivided into two sub-clusters, reflecting transitional assemblages. In particular, one branch corresponds to subassemblage IIIA reflecting the modern water column of the southern Aegean (Pujol and Vergnaud-Grazzini, 1995), while the other branch corresponds to the sub-assemblage IIIB, which is indicative of deglaciation (Casford et al., 2002; Kontakiotis et al., 2013). This assemblage is dominated by G. ruber alba and G. bulloides, and abundantly contains G. glutinata, G. rubescens, and G. inflata. Lowfrequency species also occurred in this assemblage, such as $N$. pachyderma, G. siphonifera and G. sacculifer. Its subdivision into the two sub-assemblages depends on the presence (IIIB) or absence (IIIA) of the temperate species $G$. inflata. Both faunal groups correspond to a mesotrophic environment with strong seasonal fluctuations (Rohling et al., 1993; Pujol and Vergnaud-Grazzini, 1995; Kontakiotis et al., 2013). More specifically, the coexistence of G. ruber alba, G. rubescens and N. pachyderma (indicative of stratified water column) and G. bulloides or G. inflata (indicative of homogenous water column) highlights the strong seasonal contrasts governing this assemblage.

\subsubsection{North Aegean}

4.1.2.1. Cluster I (assemblage G. bulloides). It contains 9 samples (SK22-SK25, SK27-SK28 and SK32-SK33) representing the sapropel S1. G. bulloides is dominant, with percentages reaching up to $80 \%$ of the total fauna. Elevated percentages of this species during S1 highlight the enhanced productivity due to increased riverine inputs (Geraga et al., 2010), by supplying high concentrations of dissolved nutrients, and because of low salinity stratifying the surface waters. This finding is supported by the significant presence of T. quinqueloba, and $O$. universa, which have been associated with the reduced surface salinity conditions during S1 (Zachariasse et al., 1997).

4.1.2.2. Cluster II (assemblage G. ruber alba-SPRUDTS groupG. bulloides). It contains 20 samples (SK1-SK20) and represents the upper part of the core $(0-271 \mathrm{~cm})$. This assemblage is mainly 


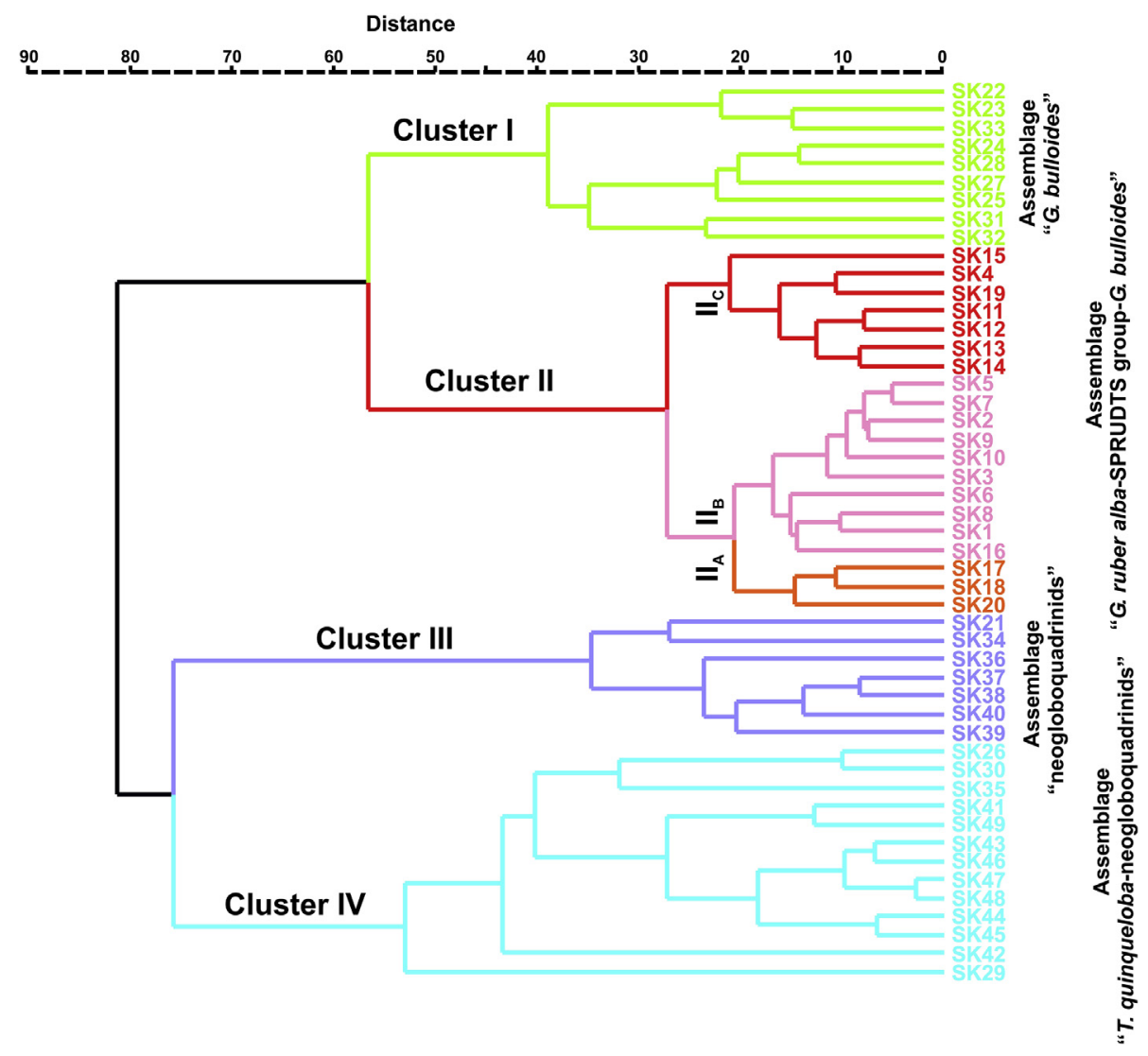

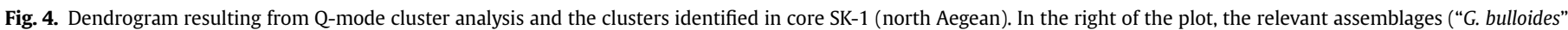

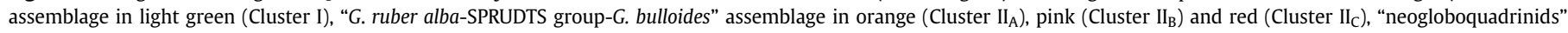

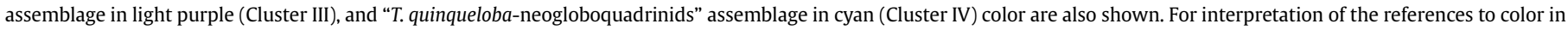
this figure legend, the reader is referred to the web version of this article.

characterized by the prevalence of both varieties of the species G. ruber. Species of the SPRUDTS group are also abundant, with G. rubescens as its main component. Next in abundance is G. bulloides, but significantly lower compared to the previous assemblage. This assemblage can be further divided into three distinct sub-clusters corresponding to 3 foraminiferal subassemblages, which show remarkable seasonal contrasts in temperature $\left(\mathrm{II}_{A}\right)$, productivity $\left(\mathrm{II}_{\mathrm{B}}\right)$ and stratification of the water column $\left(\mathrm{II}_{\mathrm{C}}\right)$, depending on the relative abundances of species involved. In sub-assemblage $\mathrm{II}_{\mathrm{A}}$ the high percentages $(>60 \%)$ of G. ruber alba combined with the maximum concentrations of T. quinqueloba (6-16\%) reveal the seasonal development of thermal stratification. In sub-assemblage $\mathrm{II}_{\mathrm{B}}$, the simultaneous presence of oligotrophic and eutrophic species suggests seasonal contrast in available food supply. Finally, in sub-assemblage II $_{C}$ the significantly high percentages $(65-90 \%)$ of the species belonging to the SPRUDTS group, and the presence of G. inflata and N. pachyderma, show seasonal contrasts in water column stratification.

4.1.2.3. Cluster III (assemblage neogloboquadriniids). It contains 7 samples (SK21, SK34 and SK36-SK40) and represents the middle part of the core corresponding mostly to T1. This assemblage is characterized by the predominance of neogloboquadriniids, accompanied by minor components of T. quinqueloba, G. bulloides, G. glutinata, G. inflata and G. ruber alba. Overall, this assemblage implies the existence of a mesotrophic to eutrophic, low-salinity environment (Rohling et al., 1993; Kontakiotis et al., 2013).
4.1.2.4. Cluster IV (assemblage T. quinqueloba-neogloboquadriniids). It contains 13 samples (SK26, SK29-SK30, SK35 and SK41-SK49), the majority of which represent the lower part of the core corresponding to the late glacial period. The species T. quinqueloba plays a dominant role, while high percentages of the neogloboquadriniids are also notable. Their high abundance in combination with the presence of typical cold-water species (e.g. G. scitula) reflects the presence of particularly cold and eutrophic water masses in the north Aegean Sea (Hayes et al., 1999; Casford et al., 2002; Geraga et al., 2005).

\subsection{Principal Component Analysis}

A standardized PCA was carried out on the total data set, in order to determine the impact of various environmental parameters on the planktonic foraminiferal distribution, and furthermore to examine whether similar or dissimilar hydrographic conditions prevailed in the two aforementioned Aegean sub-basins during T1. This analysis yielded a three- and fourfactor model in south and north sub-basins respectively. The distinguished factors were considered that account for $76.80 \%$ and $65.22 \%$ of the total variance in the south and north Aegean respectively (Tables 1 and 2), with their factor loadings showing the contribution of each factor in every sample and therefore the down-core contribution of each factor (Figs. 5A,E,G and $6 \mathrm{~A}, \mathrm{D}, \mathrm{F}, \mathrm{J})$. 
Table 1

PCA factors and their percentages of the total variability for core NS-14 (south Aegean).

\begin{tabular}{lccc}
\hline PCA factors & Eigenvalue & \% Variance & $\begin{array}{l}\text { Cumulative \% of } \\
\text { the total variance }\end{array}$ \\
\hline 1 & 284.999 & 35.944 & 35.944 \\
2 & 184.585 & 23.280 & 59.224 \\
3 & 139.394 & 17.581 & 76.805 \\
4 & 70.545 & 8.897 & 85.702 \\
5 & 47.210 & 5.954 & 91.657 \\
6 & 23.085 & 2.912 & 94.568 \\
7 & 19.062 & 2.404 & 96.972 \\
8 & 12.130 & 1.530 & 98.502 \\
9 & 10.090 & 1.273 & 99.775 \\
10 & 1.459 & 0.184 & 99.958 \\
11 & 0.276 & 0.035 & 99.993 \\
12 & 0.044 & 0.006 & 99.999 \\
13 & 0.008 & 0.001 & 100.000 \\
\hline
\end{tabular}

Table 2

PCA factors and their percentages of the total variability for core SK-1 (north Aegean).

\begin{tabular}{llcc}
\hline PCA factors & Eigenvalue & \% Variance & $\begin{array}{l}\text { Cumulative \% of } \\
\text { the total variance }\end{array}$ \\
\hline 1 & 4.005 & 33.379 & 33.379 \\
2 & 1.490 & 12.419 & 45.798 \\
3 & 1.222 & 10.180 & 55.978 \\
4 & 1.108 & 9.237 & 65.215 \\
5 & 0.940 & 7.833 & 73.048 \\
6 & 0.735 & 6.126 & 79.174 \\
7 & 0.673 & 5.609 & 84.783 \\
8 & 0.602 & 5.014 & 89.797 \\
9 & 0.520 & 4.335 & 94.132 \\
10 & 0.408 & 3.404 & 97.536 \\
11 & 0.295 & 2.461 & 99.996 \\
12 & 0.000 & 0.004 & 100.000 \\
\hline
\end{tabular}

\subsubsection{South Aegean}

The first varimax factor (PCA1) explains $35.94 \%$ of the total variance (Table 1, Fig. 5A) and exhibits a bipolar character (Table 3 ). The positive loading taxa thrive in warm, oligotrophic waters, while the negative loading taxa prefer cool/cold conditions (Rohling et al., 1993; Pujol and Vergnaud-Grazzini, 1995). Therefore, PCA1 could be considered as a temperature axis, with higher temperatures towards its positive side. The second varimax factor (PCA2) explains $23.28 \%$ of the total variance (Table 1, Fig. 5E) and is also bipolar (Table 3 ), with the one pole to be expressed positively by species living in a highly stratified water column and negatively by species typical of the weak development of these conditions. Henceforth, this is referred to as the Stratification Factor. The third varimax factor (PCA-3) accounts for $17.58 \%$ of the total variance (Table 1 , Fig. 5G), and is associated with upwelling events and overall stability of the water column. The main representative of the negative pole of PCA-3 (Table 3), G. bulloides, is directly associated with seasonal upwelling (Rohling et al., 1993). Similarly, the species that complement the negative semi-axis characterize the initial ( N. pachyderma) and the final (T. quinqueloba, N. dutertrei) stage of the upwelling period (Thunell and Sautter, 1992), or show strong preference for horizontal currents (G. glutinata, G. inflata) developed during the winter (Fraile et al., 2009). In each case, the above species are highly dependent on enhanced food levels (Hemleben et al., 1989), and therefore this factor was interpreted as indicator of high productivity. In contrast, species comprising the positive axis (G. ruber and SPRUDTS group; Table 3) characterize oligotrophic conditions that develop during the summer months when they are completely absent.

Table 3

Ranking of the planktonic foraminiferal species and their factor loadings along the PCA axes in core NS-14. Bold data indicate the most important factor loadings in each factor.

\begin{tabular}{lrrr}
\hline Variables & Factor 1 & Factor 2 & Factor 3 \\
\hline G. ruber alba & 0.122 & $-\mathbf{0 . 3 3 7}$ & $\mathbf{0 . 6 8 9}$ \\
G. ruber rosea & $-\mathbf{0 . 2 9 4}$ & $\mathbf{0 . 4 0 7}$ & $\mathbf{0 . 4 3 6}$ \\
G. bulloides & -0.072 & $-\mathbf{0 . 3 8 3}$ & $-\mathbf{0 . 2 9 7}$ \\
G. rubescens & $-\mathbf{0 . 1 9 5}$ & $-\mathbf{0 . 3 6 4}$ & $-\mathbf{0 . 2 8 5}$ \\
G. siphonifera & $-\mathbf{0 . 2 6 3}$ & 0.098 & -0.005 \\
G. sacculifer & $-\mathbf{0 . 2 2 7}$ & $\mathbf{0 . 2 8 5}$ & 0.029 \\
T. quinqueloba & $\mathbf{0 . 3 7 7}$ & $\mathbf{0 . 2 7 6}$ & -0.046 \\
G. inflata & 0.032 & -0.042 & -0.019 \\
G. scitula & $\mathbf{0 . 3 5 8}$ & 0.157 & -0.005 \\
G. glutinata & 0.037 & $\mathbf{0 . 2 5 3}$ & -0.059 \\
O. universa & $-\mathbf{0 . 3 0 0}$ & $\mathbf{0 . 3 9 4}$ & 0.058 \\
N. pachyderma & $\mathbf{0 . 4 3 3}$ & 0.109 & $-\mathbf{0 . 2 7 9}$ \\
N. dutertrei & $\mathbf{0 . 4 2 9}$ & 0.126 & -0.107 \\
\hline
\end{tabular}

\subsubsection{North Aegean}

The first varimax factor (PCA-1) accounts for $33.38 \%$ of the total variance (Table 2, Fig. 6A), and is represented by SST indicator species (Rohling et al., 1997; Antonarakou et al., 2007; Geraga et al., 2008). It exhibits a strongly dipolar character (Table 4), with the negative pole to be dominated by species indicative of cold-water masses corresponding to the glacial fauna, while the positive component by species that characterize the water column of the Holocene in the north Aegean Sea. The second axis (PCA-2), explains $12.42 \%$ of the total variance (Table 2, Fig. 6D) and is interpreted as indicator of a shallow low salinity mixed layer. Species with positive loadings (e.g. O. universa, G. sacculifer; Table 4) are associated with the low salinity layer, as a result of runoff during S1 deposition. During other times, the presence of species such as $G$. bulloides and T. quinqueloba indicates that the surface mixed layer became more eutrophic, and can be attributed to the shoaling of the pycnocline due to winter mixing and upwelling (Pujol and Vergnaud-Grazzini, 1995). In contrast, the species that exhibit negative loadings (N. pachyderma, G. scitula, G. inflata, G. ruber alba), despite the fact that they are lower compared to the corresponding positive ones (Table 4), characterize either the absence of the low salinity layer or the increase of the thermocline/nutricline depth. The third axis (PCA-3) accounts for $10.18 \%$ of the total variance (Table 2, Fig. $6 \mathrm{~F}$ ) and is associated with primary productivity. The species with positive loadings (e.g. $N$. pachyderma, G. bulloides; Table 4) show that the nutrients are restricted only to subsurface waters, while those with negative loadings (e.g. G. scitula, G. siphonifera, G. glutinata; Table 4) demonstrate that the increased primary productivity is reflected throughout the water column. The fourth varimax factor (PCA-4) was mainly defined by G. glutinata (Table 4), explaining the $9.24 \%$ of the total variance (Table 2, Fig. 6J). In contrast to the stable water conditions reflected by the positive component species, the strongly negative loading of $G$. glutinata can be considered a measure of seasonality that characterizes the water column of the north Aegean Sea. The factor of seasonality is further reinforced by the presence of G. bulloides and G. ruber alba, which are the main exponents of the seasonal contrasts governing planktonic foraminiferal assemblages in the Mediterranean Sea during the Holocene (Wilke et al., 2009; Wit et al., 2010; Goudeau et al., 2015), as well as $N$. pachyderma whose vertical distribution is affected by seasonality (Fraile et al., 2009). 
Table 4

Ranking of the planktonic foraminiferal species and their factor loadings along the PCA axes in core SK-1. Bold data indicate the most important factor loadings in each factor.

\begin{tabular}{lrrrr}
\hline Variables & Factor 1 & Factor 2 & Factor 3 & Factor 4 \\
\hline G. ruber alba & $\mathbf{0 . 7 8 5}$ & $-\mathbf{0 . 3 4 7}$ & -0.041 & -0.023 \\
G. ruber rosea & $\mathbf{0 . 7 3 4}$ & -0.135 & -0.037 & 0.123 \\
G. rubescens & $\mathbf{0 . 6 7 4}$ & $-\mathbf{0 . 3 2 1}$ & -0.191 & -0.157 \\
G. sacculifer & $\mathbf{0 . 6 1 3}$ & 0.099 & 0.058 & 0.154 \\
G. bulloides & 0.339 & $\mathbf{0 . 7 2 1}$ & 0.193 & -0.279 \\
G. siphonifera & $\mathbf{0 . 7 9 8}$ & -0.019 & -0.120 & 0.163 \\
T. quinqueloba & $-\mathbf{0 . 6 9 7}$ & 0.107 & $-\mathbf{0 . 4 4 0}$ & $\mathbf{0 . 2 6 4}$ \\
G. scitula & $-\mathbf{0 . 4 8 9}$ & -0.163 & $-\mathbf{0 . 4 2 3}$ & $\mathbf{0 . 2 8 8}$ \\
G. glutinata & $-\mathbf{0 . 2 9 3}$ & -0.205 & -0.045 & $-\mathbf{0 . 8 2 2}$ \\
O. universa & 0.034 & $\mathbf{0 . 7 2 6}$ & -0.018 & 0.062 \\
G. inflata & -0.058 & -0.152 & $\mathbf{0 . 7 4 3}$ & $\mathbf{0 . 3 2 8}$ \\
Neogloboquadrinids & $-\mathbf{0 . 6 7 4}$ & $-\mathbf{0 . 2 9 7}$ & $\mathbf{0 . 4 4 6}$ & -0.008 \\
\hline
\end{tabular}

\subsection{Stable isotopes}

The stable oxygen $\left(\delta^{18} \mathrm{O}\right)$ and carbon $\left(\delta^{13} \mathrm{C}\right)$ isotopes performed on core NS-14 (Fig. 5C,J) show a two-step deglaciation and a more stable warm and dry Holocene. At the lower part of the studied core, the $\delta^{18} \mathrm{O}$ curve exhibits heavy values $(+1.04$ to $+2.75 \%$ ) suggesting the prevalence of cold sea surface waters. The heaviest $\delta^{18} \mathrm{O}$ values occurred at $\sim 14.1$ and $13.3 \mathrm{ka}$ and correspond to the short Older Dryas (OD) and Intra Allerød Cold Period (IACP) events. A gradual depletion ranges from +2.75 to $+0.78 \%$ pointing to relatively warmer and less saline waters. The subsequent reduction of about 2.0\% at the top of this period (Bølling-Allerød; B-A) reflects the transition to the warm climate of the period Allerød, while the positive $\delta^{13} \mathrm{C}$ values indicate the enrichment of water nutrients. The $\delta^{18} \mathrm{O}$ value corresponding to the beginning of the cold and dry Younger Dryas (YD) period is heavier $(+1.04 \% 0)$, implying re-cooling of the water column of the Aegean Sea. Unfortunately, the presence of a turbidity horizon at this point does not allow for a detailed observation of the YD climate in order to insure the two phases recognized by the paleoclimatic indices of this period. However, the value which characterizes the YD is representative of this period as it is within the narrow context of isotope measurements have been recorded in all sub-basins of eastern Mediterranean Sea (Geraga et al., 2000, 2005, 2008, 2010; Casford et al., 2002; Fhlaithearta et al., 2010). Thereafter, steadily low $\delta^{18} \mathrm{O}$ values suggest the climatic amelioration of the Holocene. More explicitly, during the Holocene the $\delta^{18} \mathrm{O}$ values ranging from -0.99 to $+0.42 \%$ and characterize a fairly warm environment with small fluctuations corresponding to decrease in temperature (Holocene Cold Episodes - Bond et al., 2001; Mayewski et al., 2004) and/or increase of surface salinity. The negative $\delta^{13} \mathrm{C}$ values during the deposition of S1 and SMH are suggestive of increased water supply in the water column.

\section{Discussion}

\subsection{Ecological significance of the planktonic foraminiferal taxa}

The value of planktonic foraminifera as indicators of Quaternary paleoceanographic and/or paleoclimatic changes in the Aegean Sea sediments has been previously demonstrated by several authors (Rohling et al., 1993, 1997; Geraga et al., 2000, 2005, 2010; Casford et al., 2003; Triantaphyllou et al., 2007, 2009a, 2010; Kontakiotis, 2012; Kontakiotis et al., 2013). The species G. ruber alba, G. ruber rosea, G. sacculifer, G. siphonifera, O. universa and G. rubescens are considered as indicative of warm (subtropical) and oligotrophic waters, whereas N. pachyderma, N. dutertrei, T. quinqueloba, G. glutinata and G. scitula are considered as indicative of cool conditions (Rohling et al., 1993; Lourens et al., 1994).

Turborotalita quinqueloba is also tolerant to fairly low salinity and/or enhanced fertility in surficial waters (Rohling et al., 1993). Globorotalia inflata and Globorotalia truncatulinoides indicate an isothermal water column throughout the euphotic zone (Coulbourn et al., 1980; Pujol and Vergnaud-Grazzini, 1995), as a consequence of the strong convective mixing (Negri et al., 1999). In the eastern Mediterranean, their coexistence is mainly associated with seasonal mixing of water during autumn/winter (Pujol and Vergnaud-Grazzini, 1995; Rohling et al., 1995), and indicates the presence of intermediate water masses, with the intense action of Levantine Intermediate Waters (LIW) in the south Aegean Sea (Rohling et al., 1997; Triantaphyllou et al., 2009a). Particularly, G. inflata is a transitional species between subtropical and subpolar water masses that prefers to live at the bottom of thermocline depths (Hemleben et al., 1989). G. bulloides is a species which lives in the surface or subsurface waters withstanding large fluctuations in temperature, salinity and density of the water column (Rohling et al., 1993). It is also highly dependent on enhanced food levels (upwelling, strong seasonal mixing or fresh water inputs) (Rohling et al., 1993). The species G. sacculifer, G. ruber rosea, G. siphonifera and 0 . universa (SPRUDTS group) indicate a warm and strongly stratified water column, which characterizes most of the Holocene, and especially S1. Their abundance is mainly controlled (beyond temperature) by the stratification of the water column (Rohling et al., 1997). They occur close to the surface, where solar radiation is maximized, and in the low fertility mixed layer, characterized by a strong vertical stratification of surface waters during the summer months (Hemleben et al., 1989). N. pachyderma and $N$. dutertrei thrive in cool water, in particular in oceanographic regions where a shallow nutricline favors the formation of a DCM at the base of the euphotic layer (Fairbanks and Wiebe, 1980), and therefore their high abundances suggest stratified conditions within the euphotic layer. Although both representatives indicate the development of a nutrient-rich, low-salinity environment, they present different depth habitat and therefore they can be used as indicators of the overall position of the subsurface thermocline (Faul et al., 2000). G. glutinata is a shallow-living $(\sim 75 \mathrm{~m})$ cosmopolitan species spreading within a wide range of temperature and salinity, which can survive both oligotrophic and eutrophic conditions (Hemleben et al., 1989; Reiss et al., 2000; Mazumder et al., 2009). Its presence in the Aegean Sea species has been associated with the spring bloom, triggered by the newly available nutrients at the end of the winter mixing and increased solar irradiation (Casford et al., 2002).

\subsection{Factors controlling the spatial and temporal planktonic foraminiferal variability in the Aegean Sea}

As shown here and in previous studies, SST is the dominant factor controlling the biogeography of planktonic foraminifera at both global (Kucera et al., 2005), and local (Kontakiotis et al., 2011) scale. Of the typically considered oceanographic factors in the Aegean Sea, SST (PCA-1) shows the highest explanatory power for planktonic foraminifera distribution during the Late Quaternary. However, the remaining factors (PCA-2, PCA-3, PCA-4) exhibit a bipolar character and could be considered as indicators of the annual stability of the water column. They show that the faunal composition in the Aegean Sea was not only controlled by SST, but also seems to be affected by the degree of development and location of a permanent or seasonal thermocline/pycnocline. Its vertical placement in the water column is a direct consequence of changes in sea surface salinity and productivity, which reflect seasonal changes in vertical mixing. The interpretation of the second axis focuses on the pycnocline and DCM depths and the mixed layer 


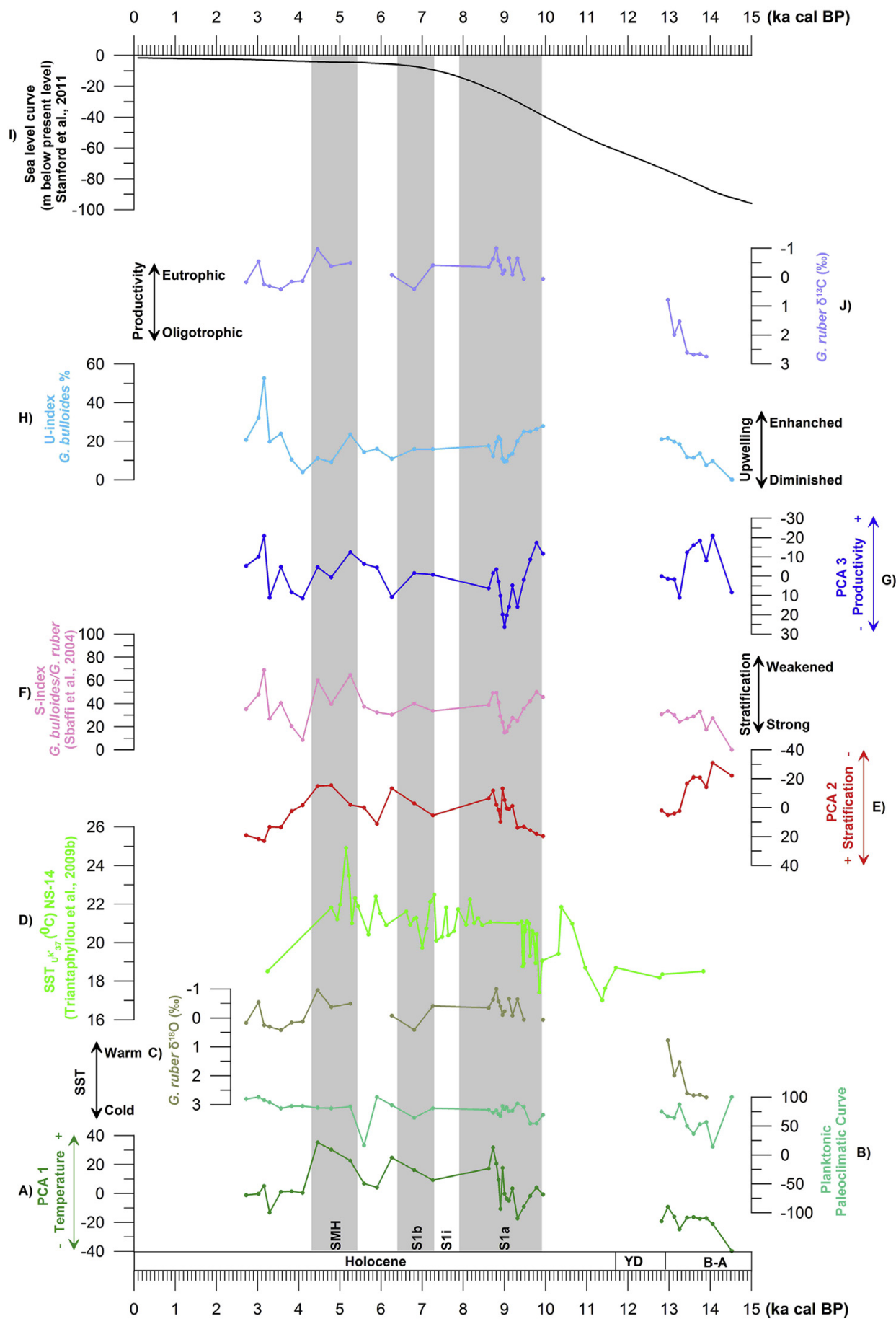

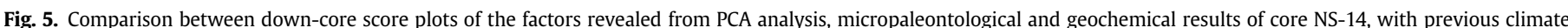

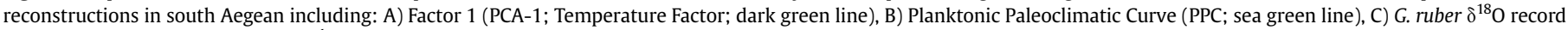

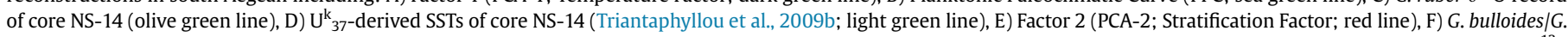

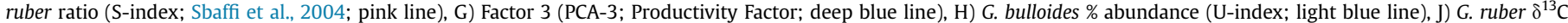

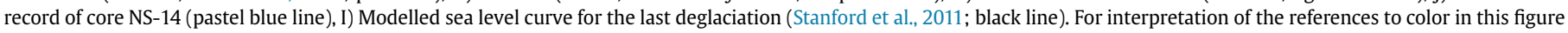
legend, the reader is referred to the web version of this article.

thickness, while the interpretation of the third axis focuses on upwelling/downwelling and/or river freshwater inputs, parameters that primarily control food availability and foraminifera reproductive cycles (Hemleben et al., 1989) and are directly correlated with the seasonal fluctuations (Žarić et al., 2005; Fraile et al., 2009; Wilke et al., 2009). Therefore, a useful additional dimension of planktonic foraminifera ecology highlighted by the PCA approach here is the degree of vertical stratification, which is inextricably linked with the factors of primary productivity and seasonality.

\subsection{Paleoenvironmental reconstruction}

The results of the multivariate statistical records, in combination with the foraminiferal abundance and isotopic data, reveal a series 
$\begin{array}{llllllllllllllllllllll}0 & 1 & 2 & 3 & 4 & 5 & 6 & 7 & 8 & 9 & 10 & 11 & 12 & 13 & 14 & 15 & 16 & 17 & 18 & 19 & 20 & \text { (ka cal BP) }\end{array}$

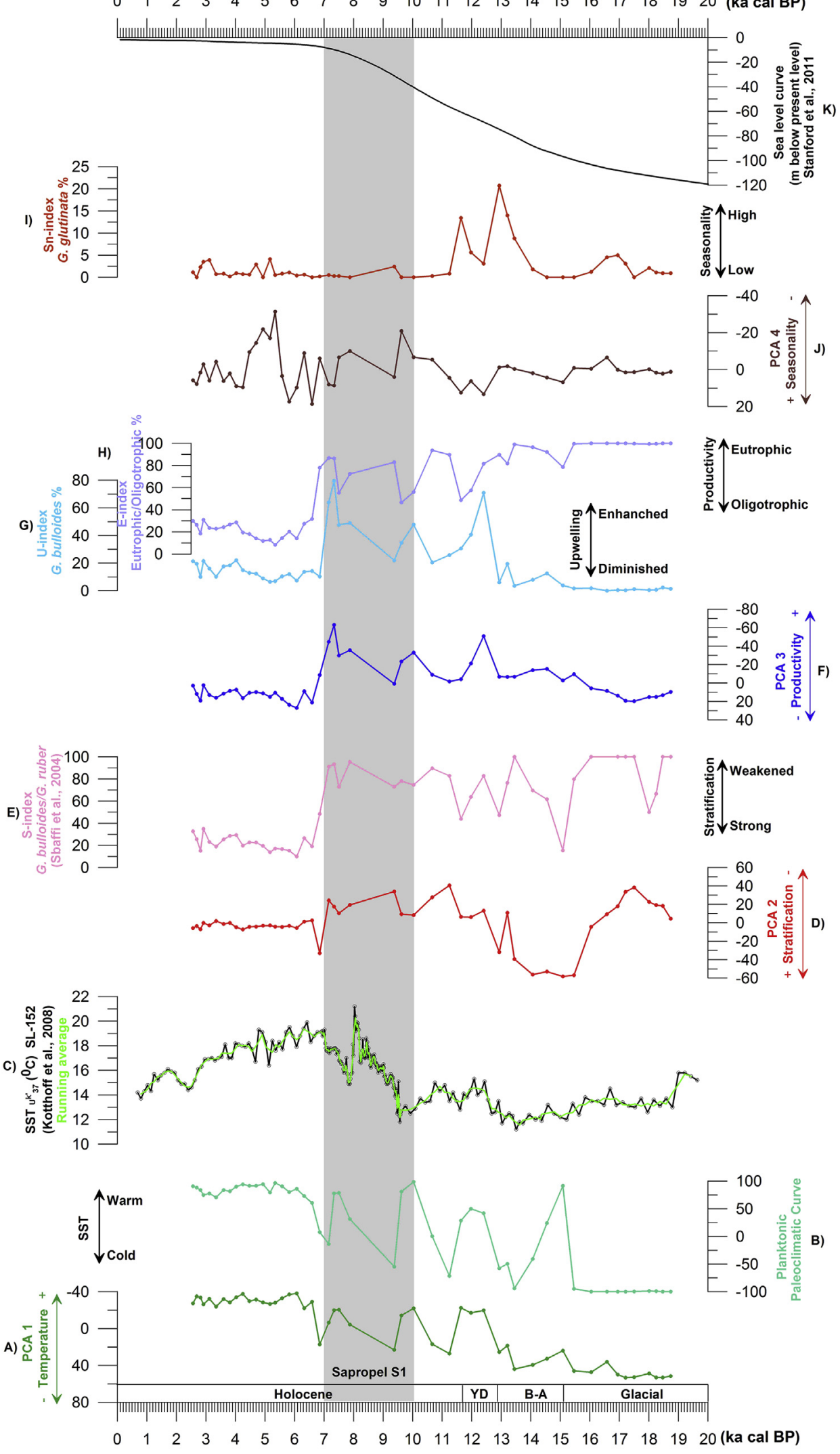

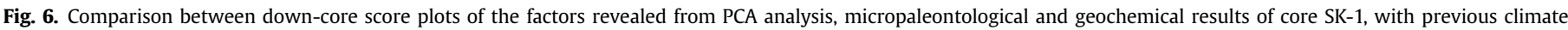

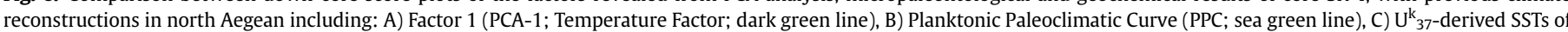

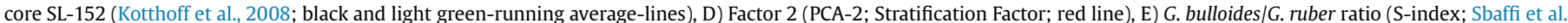

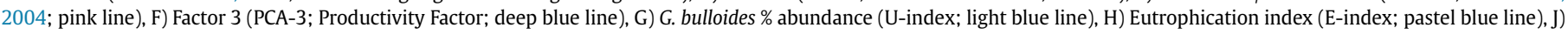

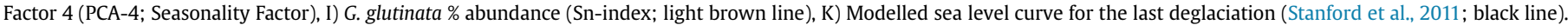
For interpretation of the references to color in this figure legend, the reader is referred to the web version of this article. 


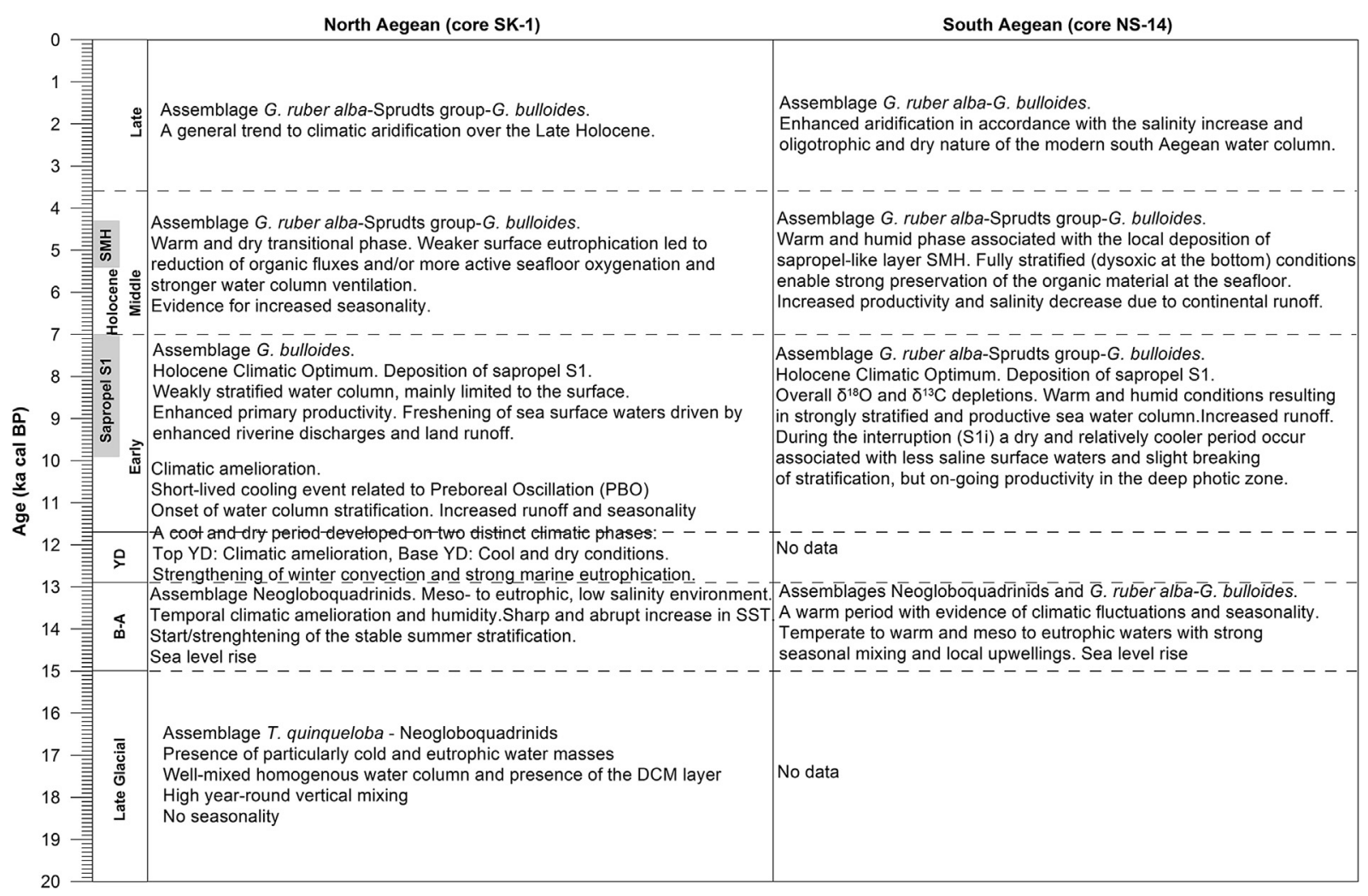

Fig. 7. Correlation scheme between the planktonic foraminiferal assemblages and the corresponding paleoclimatic and paleoenvironmental changes identified in analyzed cores from north and south Aegean basins during the late Quaternary.

of late glacial to Holocene paleoclimatic and paleoceanographic changes in both the north and south Aegean Sea, presented in Figs. 5 and 6 and summarized in Fig. 7. The evidence of these changes is interpreted and discussed in terms of the events that mainly accompanied the transition out of the Late Pleistocene glacial, and the deposition of the sapropel S1 during the Holocene Climatic Optimum. Data are compared with other proxies related to oceanographic information such as census of planktonic foraminifera, sea level changes, $U^{k}{ }_{37}$ SST records of the same or nearby cores, published elsewhere (Gogou et al., 2007; Kotthoff et al., 2008; Triantaphyllou et al., 2009b; Geraga et al., 2010) (Figs. 5D and $6 \mathrm{C}, \mathrm{K})$.

\subsubsection{Late glacial period (19.0-15.1 ka)}

The late glacial paleoclimate phase is characterized by high percentages of cold-water species such as T. quinqueloba, G. scitula and species related to eutrophic waters such as N. pachyderma and G. glutinata (Fig. 7). Such an assemblage, accompanied with low values of both PPC and Factor 1 (PCA-1; Fig. 6A,B), as well as the absence of oligotrophic species suggests low SST during the glacial period which have been also documented by previously reconstructed $\mathrm{U}^{\mathrm{k}}{ }_{37}$-derived SSTs in nearby MNB3 and SL152 north Aegean cores (Gogou et al., 2007; Kotthoff et al., 2008 - Fig. 6C). Relatively high values of Factor 2 (PCA-2; Stratification Factor Fig. 6D) and of the ratio G. bulloides/G. ruber (S-index - Fig. 6E) during this period suggest less stratified surface waters, pointing towards high vertical mixing. This is in accordance with the findings of a well-mixed, homogenous (little density contrast) water column in north Aegean Sea, as witnessed by the similar isotopic signal obtained on planktonic foraminifera dwelling in different water masses (Casford et al., 2002). Furthermore, Factor 3 (PCA-3; Productivity Factor - Fig. 6F), an indicator of eutrophic conditions agrees with the other alternative records (Fig. 6G,H). The surface water productivity conditions are controlled primarily by the winter wind induced vertical mixing and/or upwelling invoking injection of nutrient into the photic zone. Since SK-1 provide valuable data of minimal seasonal upwelling during late glacial (lowest values of the U-index - Fig. 6G), the primary productivity evolution of the region should be attributed to the winds. Atmospheric models indicate intensification and southward shifting of the westerly winds around this time interval, which may lead to extensive overturning of the water column (Kutzbach and Guetter, 1986). The development of eutrophicated waters is also supported by the high abundance of $N$. pachyderma (DCM-indicator) and the temporal increase of marine biomarkers (Gogou et al., 2007). This year-round mixing is also consistent with the relatively low values of the Factor 4 (PCA-4; Seasonality Factor - Fig. 6J) and of the seasonality index (Sn-index - Fig. 6I). However, the presence of extensive massive flows in NS-14 core limits the ability to interpret these features in the south Aegean Sea.

\subsubsection{Deglaciation (15.1-11.7 ka)}

This glacial circulation appears to alter with the start of termination T1a. The onset of the last deglaciation, dated at $15.1 \mathrm{ka}$ (Fig. 7), is characterized by a sharp and abrupt increase in SST which took place over a period of 200-300 years. This trend is in agreement with all records from the eastern Mediterranean and is attributed to the Bølling-Allerød (Asioli et al., 2001; Kotthoff et al., 2008, 2011; Dormoy et al., 2009). At that time, a shift in environment is clearly indicated in both the fauna and the isotopic data. During this very rapid warming phase, the PCA-1 and the PPC records of both Aegean sub-basins reveal high values (especially the latter up to $80 \%$; Figs. $5 \mathrm{~A}, \mathrm{~B}$ and $6 \mathrm{~A}, \mathrm{~B}$ ). The abrupt rise of the paleoclimatic curves is characterized by the higher abundances of $G$. 
ruber alba, G. bulloides, G. inflata and G. truncatulinoides, which are indicative of changing conditions of deposition, suggesting temperate to warm and meso-to eutrophic waters, with strong seasonal mixing and local upwellings. This warming trend is more obvious in the northern site (SK-1), while in the southern Aegean site (NS-14) a smoother shift towards higher values for PPC is observed (Fig. 5B), consistent with a progressively shift to lighter G. ruber $\delta^{18} \mathrm{O}$ values (Fig. $5 \mathrm{C}$ ) indicative of the temporal climatic amelioration and humidity. The difference in PPC records is indicative of the more pronounced SST variability in the north compared to south Aegean during the transition from late glacial to the deglaciation, which is also recorded in the alkenone-SSTs (Kotthoff et al., 2008; Triantaphyllou et al., 2009b) (Figs. 5D and 6C). Additionally, the increased SST and humidity are also recorded by the higher abundance of the terrestrial biomarkers in the studied basins (Gogou et al., 2007; Triantaphyllou et al., 2009b), and by a change in the benthic faunas from oxic to dysoxic indicator species (Kuhnt et al., 2007). However, this climatic trend of progressive improvement seems to be interrupted by two episodes indicating the climatic instability of this period. The PCA- 1 and PPC curves indicate rapid drops in temperature at around 14.1 and $13.3 \mathrm{ka}$ in both Aegean basins linked with OD and IACP events (Figs. 5A,B, $6 A, B)$. Similar climatic fluctuations have been recorded in the entire Mediterranean basin (Asioli et al., 2001; Cacho et al., 2001; Geraga et al., 2008, 2010; Kotthoff et al., 2011).

The subsequent regime is also characterized by the start/ strengthening of the summer stratification, as indicated by the relatively low values of PCA-2 and S-index in both Aegean basins (Figs. 5E,F; 6D,E). The significant occurrence of the mixed layer species G. ruber, together with the presence in N. pachyderma suggest the development/strengthening of a stable summer thermocline in a generally well oxygenated environment. Moreover, the productivity proxy records (PCA-3, Upwelling and Eutrophication indexes - Figs. $5 \mathrm{H} ; 6 \mathrm{G}, \mathrm{H}$ ) indicate an enhanced primary productivity during this part of the deglaciation. The planktonic foraminiferal records (e.g. G. bulloides \%) indicate changes on primary productivity and nutrient availability, which are controlled by the vertical mixing but also the supply from the continent. The enhancement of terrestrial inputs during this time is probably related to a rapid sea level rise (Figs. 5I and 6K) and an increased supply from riverine inputs that transferred terrestrial organic matter from the continental shelf to the basins (Roussakis et al., 2004). In addition, studies of African lake levels and Aeolian dust influxes (DeMenocal et al., 2000) suggest that this period corresponds to the start of a regional humidity increase known as the African Humid Phase (AHP). Such an increase in freshwater budget would have increased surface buoyancy, and consequently could explain the establishment of the seasonal stratification recorded in the records.

This state persisted until the onset of the YD at about $12.9 \mathrm{ka}$, which is recorded only in core SK-1 due to the presence of a turbidite in core NS-14 (Fig. 7). The fauna shows an abrupt increase of cold water species and the near absence of warm mixed layer species, reflecting a pronounced cooling of surface waters that are also recognized in the $\mathrm{U}^{\mathrm{k}}{ }_{37}$-SST records (Gogou et al., 2007; Kotthoff et al., 2008 - Fig. 6C). At the base of this zone, a rapid cooling recorded by the drastic change in foraminiferal assemblages and the decline of the PCA-1 and PPC records (Fig. 6A,B) marks the start of this cooling phase. However, the records show that these conditions did not prevail until the end of YD. The initial cooling was accompanied with mild climatic conditions reflected by an increase in both the above records and an abrupt shift in the PCA-2 and G. bulloides/G. ruber ratio (Fig. 6D,E). The latter coincides with the increase of both the mixing and upwelling indicators $G$. inflata and $G$. bulloides respectively, suggesting a strengthening of winter convection during this period. Relatively high values of the productivity factor (PCA-3) and the E-index (Fig. 6F,H) also suggest strong marine eutrophication attributed to the enhanced vertical mixing and upwelling phenomena. The development and the interpretation of the YD event in two phases (with the second phase less cold, arid and more gradual than the first one) has been recorded in the planktonic foraminifera and in marine data from the north Aegean Sea (Geraga et al., 2010), the Ionian Sea (Geraga et al., 2008) the western Mediterranean Sea (Cacho et al., 2001) as well as in north Aegean terrestrial data (Dormoy et al., 2009). The climatic amelioration at mid-time in the YD event has been attributed to a displacement of the polar front by a few degrees north (Cacho et al., 2001).

\subsubsection{Holocene (11.7 ka to present)}

With the ending of the YD, a general climatic amelioration is seen in the records until the Holocene, with the exception of the short-lived cooling event at around $11.3 \mathrm{ka}$, which may be related to the PreBoreal Oscillation (PBO - Fig. 7). According the alkenonebased SST reconstructions in cores NS-14 and SL-152 (Kotthoff et al., 2008; Triantaphyllou et al., 2009b) the amplitude of this event is largest in south than in north Aegean Sea. Coinciding with the decline of the temperature factor (PCA-1) and PPC records (Fig. 6A,B), G. glutinata replaces G. inflata. This may be tentatively explained in terms of increased seasonality, and of increased freshwater input which reduced surface buoyancy loss and hence suppressed mixing during the transition to the Holocene.

By $10.0 \mathrm{ka}$, deposition of sapropel S1 commenced, and it coincides with the start of the overall $\delta^{13} \mathrm{C}$ depletion (Fig. 5J) and the faunal shift to a virtually complete dominance of mixed layer species. Minor age discrepancies concerning the initiation of S1 and/or the differentiation of the sapropel subunits S1a and S1b in the analyzed cores reflect the local conditions of marine circulation, depositional depth and the amount of the organic material that reached the sea floor. High values on the PCA- 1 and the PPC records (Fig. 5A,B; 6A,B) together with the steadily low $\delta^{18} \mathrm{O}$ values (Fig. 5C) reflect a climatic invasion towards high temperatures, with the only exception of three events (obtained mostly before the starting and at the end of the sapropel S1 deposition, as well as at the S1 interruption) where lower PPC values reflect lower SSTs during the Holocene. These cooling events are reflected by significant faunal changes in the eastern Mediterranean, such as the arrival of neogloboquadrinids and the sudden increase in abundance of $T$. quinqueloba and $G$. inflata, replacing the tropical fauna of G. sacculifer and SPRUDTS group (Rohling et al., 1993, 1997). Concurrently $U^{k}{ }_{37}-S S T$ reconstructions in both the north and south Aegean basins (Gogou et al., 2007; Kotthoff et al., 2008; Triantaphyllou et al., 2009b) reveal a warming trend that reflects the changing regional climatic conditions in which the eastern Mediterranean became warmer during the Holocene Climatic Optimum. This paleoclimate change coincides with the Holocene summer precession-related insolation maximum in the Northern Hemisphere (Laskar et al., 2004), and the monsoon intensification that resulted in a widespread increase in humidity over the Mediterranean region and concomitant increase of freshwater input to the Mediterranean Sea (Rossignol-Strick, 1983; Rohling, 1994). These warm and humid conditions enhanced riverine inputs and resulted in low salinity and eutrophic waters (large depletions in $\delta^{18} \mathrm{O}$ values, high values in G. bulloides/G. ruber ratio Fig. 5C,F).

However, the comparison of the north and south Aegean records shows significant changes among the north and south Aegean basins in both the productivity and the stratification of the upper water column during this time period (Fig. 7). In accordance with previous observations from the Aegean Sea (Geraga et al., 2010), the 
elevated percentages of the species $G$. bulloides and T. quinqueloba within S1 are more pronounced in the north than in south Aegean, and are related to low salinity and high fertility of the surficial waters (Rohling et al., 1997; Zachariasse et al., 1997), possibly due to the larger river inflows draining the north Aegean land. The NS-14 $\delta^{13} \mathrm{C}$ signatures (Fig. 5J) reveal that the rainfall was more intense during the lower (S1a) sapropel layer, while the G. bulloides and T. quiqueloba abundance records of SK- 1 show that the freshening of sea surface waters driven by enhanced riverine discharges and land runoff due to intensified rainfall was greater towards the end of the sapropel (within the S1b layer). This is further supported by the contribution of Black Sea outflow after 8 ka (Sperling et al., 2003). However, there is evidence of different degrees of stratification between north and south Aegean basins during the S1 deposition. The high values of the stratification factor (PCA-2) and the G. bulloides/G. ruber ratio in core SK-1 (Fig. 6D,E) show a weakly stratified water column, while the smoother shift towards lower values for these indexes observed in core NS-14 (Fig. 5E,F) indicates a strongly stratified water column. This is further supported by the difference of the abundances of the symbiont-bearing species ( $G$. ruber alba, G. ruber rosea, G. rubescens, O. universa, G. siphonifera) between the two basins, showing the significant increase of the depth and the extent of the thermocline in the south Aegean Sea. This assemblage suggests that stratification in the south Aegean is not limited to the surface, but it is continuous throughout the euphotic layer. In contrast, in the north Aegean Sea the stratification is mainly restricted to the surface, and enhanced productivity (high E-index and productivity factor PCA-3 values - Fig. 6F,H) plays the most important role in the formation of S1. Overall, this climatic and oceanographic setting, as indicated by warm, productive and stratified water column is related to increased preservation of organic matter (Rohling and Gieskes, 1989) and the deposition of S1 in the entire Aegean Sea.

During the Mid-Holocene, the most pronounced environmental difference seems to be evident between 5.4 and $4.3 \mathrm{ka}$, where there are significant changes among the north and south Aegean basins (Fig. 7). Although all temperature-records (PCA-1, PPC, Uk37-derived SSTs - Fig. 5A,B,D) show a relatively warm period in both basins, it seems that it is correlated with the deposition of a sapropel-like layer (SMH; Triantaphyllou et al., 2009b, 2013) only in the southern and shallower site. Core NS14 recorded high numbers of the planktonic species G. bulloides and G. sacculifer, which are indicative of increased productivity and salinity decrease due to continental runoff. Taken together, these observations with the high $\delta^{13} \mathrm{C}$ values (indicative of wetter conditions; Fig. 5J) suggest an increased supply of freshwater to the NS-14 core site. Moreover, the planktonic stratification S-index (Fig. 5F) indicate well stratified conditions, which are consistent with the findings of Triantaphyllou et al. (2009b) about dysoxic conditions at water column-sediment interface, using benthic foraminifera assemblages and loliolide-isololiolide ARs. In contrast, despite the fact that the water column in north Aegean was stratified (low values of PCA-2 and G. bulloides/G. ruber ratio - Fig. 6D,E), low TOC concentrations of core SK-1 (Zachariasse et al., 1997) and the concomitant reduction of marine productivity (low values of upwelling and eutrophication indexes - Fig. 6G,H) did not allow the deposition of the sapropellike layer. In support of this interpretation, low ARs of marine and terrestrial biomarkers and elevated $\delta^{15} \mathrm{~N}$ values from nearby north Aegean cores (Gogou et al., 2007; Triantaphyllou et al., 2013) indicate that the deep north Aegean basin was fully oxygenated, thus preventing the burial of organic matter and organic-rich deposition. This Mid-Holocene warm and humid phase provides evidence of on-going, although weak, Mid Holocene African monsoon forcing in the south Aegean Sea
(Triantaphyllou et al., 2009b) that apparently was even more weakened in north Aegean Sea. The termination of this humid phase as reflected by the positive average $\delta^{13} \mathrm{C}$ values support the idea of a general trend to climatic aridification over the Late Holocene, which is in accordance with the salinity increase and oligotrophic and dry nature of the water column of the modern Aegean Sea. This is further associated with the reduction in the rate of sea-level rise at about $4.0 \mathrm{ka}$ in the Aegean Sea (Pavlopoulos et al., 2011), the northern Hemisphere rapid climate cooling at 4.2 ka mega drought event (Mayewski et al., 2004), the concomitant reduction of Black Sea surface water outflow (Sperling et al., 2003), and the termination of the African Humid Period at 3.8 ka (Jung et al., 2004).

\section{Conclusions}

This study highlights the planktonic foraminiferal abundance variations during the last glacial cycle from two gravity cores (SK1 and NS-14) along the Aegean Sea. The micropaleontological data and $G$. ruber stable isotopic analyses, integrated by multivariate statistical (Q-mode and PCA) analyses, have led to a paleoclimatic and paleoenvironmental reconstruction of the last $19 \mathrm{ka}$ in both the north and south Aegean Sea. During the late glacial, the study area was located about $120 \mathrm{~m}$ below the current sea level (Lambeck and Purcell, 2005; Karageorgis et al., 2012) with the glacial environment characterized by a year-round, well-mixed, homogenous water column with low SSTs and high eutrophication levels (Kontakiotis, 2012; Kontakiotis et al., 2013). The time interval of 15.1-12.9 $\mathrm{ka}(\mathrm{B}-\mathrm{A})$ reflects a window of relative instability in the upper water column, as a result of the onset of the African Humid Phase and associated winds, together with an increased precipitation and river runoff. During this warm and humid climatic phase, a marked seasonality led to paleoceanographic conditions characterized by efficient vertical (mainly upwelling) mixing during the winter and by a stratified water column with warm oligotrophic surface waters during the summer. This change in circulation and productivity pattern from the late glacial to the deglaciation was driven by the combination of climatic warming and rising sea levels at the onset of the B-A. This state persisted until the onset of the YD, where a strengthening of winter convection and strong water column eutrophication is recorded in both basins. However, all records indicate an abrupt cooling at its base followed by mild climatic conditions at the top of this period. With the ending of the YD, a general climatic amelioration is seen to the Holocene, with the exception of the short-lived cooling event (PBO) at around $11.3 \mathrm{ka}$. After $10.0 \mathrm{ka}$, the deposition of sapropel S1 is evident in both Aegean basins, accompanied by warm and humid conditions and the increase of the stratification of the upper water column, as a result of the climatic amelioration at Early Holocene and throughout the Holocene Climatic Optimum. The comparison between SK-1 and NS-14 records indicated significant changes in both the productivity and stratification Holocene patterns, with the former the main factor in the north Aegean and the latter in the south Aegean for the S1 deposition. However, the most pronounced environmental change recorded during the interval 5.4-4.3 ka, related to the localized deposition of SMH in the semi-enclosed shallow south Aegean site. It seems that the relatively warm and humid conditions coupled with productive and fully stratified water column recorded during this period in the south Aegean enabled the SMH deposition. In contrast, drier climate, weakened primary productivity and water column oxygenation were the limiting factors for the burial of organic matter and organic-rich layer deposition. 


\section{Acknowledgments}

The author is grateful to Professor W.J. Zachariasse and Associate Professor M. Triantaphyllou for providing the study material. Professor Dr. Peter Graham Mortyn is warmly thanked for his constructive suggestions that helped to improve the manuscript. Constructive comments by two anonymous reviewers have been essential in improving this manuscript, and Dr. Norm Catto (Editorin-Chief) is thanked for his editorial handling. This research has be co-financed by the European Union (European Social Fund-ESF) and Greek national funds through the Operational Program "Education and Lifelong Learning" of the National Strategic Reference Framework (NSRF)-Research Funding Program: THALIS-UOA-Island biodiversity and cultural evolution: Examples from the Eastern Mediterranean, Madagascar, Mauritius and Philippines during the past 800,000 years (MIS375910, KA:70/3/11669).

\section{References}

Antonarakou, A., Drinia, H., Tsaparas, N., Dermitzakis, M.D., 2007. Micropaleontological parameters as proxies of late Miocene surface water properties and paleoclimate in Gavdos Island, eastern Mediterranean. Geodiversitas 29, 379-399.

Asioli, A., Trincardi, F., Lowe, J.J., Aritzegui, D., Langone, L., Oldfield, F., 2001. Submillennial scale climatic oscillations in the central Adriatic during the Late glacial: paleoceanographic implications. Quaternary Science Reviews 20, 11201-11221.

Bond, G., Kromer, B., Beer, J., Muscheler, R., Evans, M.N., Showers, W., Hoffmann, S., Lotti-Bond, R., Hajdas, I., Bonani, G., 2001. Persistent solar influence on North Atlantic climate during the Holocene. Science 294, 2130-2136.

Cacho, I., Grimalt, J.O., Canals, M., Sbaffi, L., Shackleton, N., Schönfeld, J., Zahn, R., 2001. Variability of the western Mediterranean Sea surface temperatures during the last 25,000 years and its connection with the Northern Hemisphere climatic changes. Paleoceanography 16 (1), 40-52. http://dx.doi.org/10.1029/ 2000PA000502.

Capotondi, L., Borsetti, A.M., Morigi, C., 1999. Foraminiferal ecozones, a high resolution proxy for the Late Quaternary biochronology in the central Mediterranean Sea. Marine Geology 153, 253-274.

Casford, J.S.L., Abu-Zied, R., Rohling, E.J., Cooke, S., Boessenkool, K.P., Brinkhuis, H., De Vries, C., Wefer, G., Geraga, M., Papatheodorou, G., Croudace, I., Thomson, I., Lykousis, V., 2001. Mediterranean climate variability during the Holocene. Mediterranean Marine Science 2/1, 45-55.

Casford, J.S.L., Rohling, E.J., Abu-Zied, R., Cooke, S., Fontanier, C., Leng, M., Lykousis, V., 2002. Circulation changes and nutrient concentrations in the late Quaternary Aegean Sea: a nonsteady state concept for sapropel formation. Paleoceanography 17 (2), 1024-1034.

Casford, J.S.L., Rohling, E.J., Abu-Zied, R.H., Jorissen, F.J., Leng, M., Thomson, J., 2003. A dynamic concept for eastern Mediterranean circulation and oxygenation during sapropel formation. Palaeogeography Palaeoclimatology Palaeoecology 190, 103-119.

Casford, J.S.L., Abu-Zied, R.H., Rohling, E.J., Cooke, S., Fontanier, C., Leng, M., Millard, A., Thomson, J., 2007. A stratigraphically controlled multiproxy chronostratigraphy for the eastern Mediterranean. Paleoceanography 22, PA4215. http://dx.doi.org/10.1029/2007PA001422.

Coulbourn, W.T., Parker, G.L., Berger, W.H., 1980. Faunal and solution patterns of planktonic foraminifera in surface sediments of the North Pacific. Marine Micropaleontology 5, 329-399.

Davis, J.C., 1973. Statistics and Data Analysis in Geology. Wiley, New York.

DeMenocal, P., Ortiz, J., Guilderson, T., Sarnthein, M., 2000. Coherent high- and low latitude climate variability during the Holocene warm period. Science 288, 2198-2202.

Dormoy, I., Peyron, O., Combourieu-Nebut, N., Goring, S., Kotthoff, U., Magny, M., Pross, J., 2009. Terrestrial climate variability and seasonality changes in the Mediterranean region between 15,000 and 4000 BP deduced from marine pollen records. Climates of the Past 5, 615-632.

Drinia, H., Antonarakou, A., Anastasakis, G., 2014. Late Quaternary micropalaeontological record of a semi-enclosed marine basin, North Evoikos, central Aegean Sea. Quaternary International 345, 18-31.

Fairbanks, R.G., Wiebe, P.H., 1980. Foraminifera and chlorophyll maximum: vertical distribution, seasonal succession, and paleoceanographic significance. Science 209, 1524-1526.

Faul, K., Ravelo, A., Delaney, M., 2000. Reconstructions of upwelling, productivity, and photic zone depth in the eastern equatorial Pacific Ocean using planktonic foraminiferal stable isotopes and abundances. Journal of Foraminiferal Research 30, $110-125$.

Fhlaithearta, Ní S., Reichart, G.-J., Jorissen, F.J., Fontanier, C., Rohling, E.J., Thomson, J., De Lange, G.J., 2010. Reconstructing the seafloor environment during sapropel formation using benthic foraminiferal trace metals, stable isotopes, and sediment composition. Paleoceanography 25, PA4225. http:// dx.doi.org/10.1029/2009PA001869.

Fraile, I., Mulitza, S., Schulz, M., 2009. Modeling planktonic foraminiferal seasonality: implications for sea surface temperature reconstructions. Marine Micropaleontology $72,1-9$.

Geraga, M., Tsaila-Monopoli, St., Ioakim, Ch., Papatheodorou, G., Ferentinos, G. 2000. An evaluation of paleoenvironmental changes during the last $18000 \mathrm{yrs}$ BP in the Myrtoon Basin, S.W. Aegean Sea. Palaeogeography Palaeoclimatology Palaeoecology 156, 1-17.

Geraga, M., Tsaila-Monopolis, St., Ioakim, Chr., Papatheodorou, G., Ferentinos, G., 2005. Short-term climate changes in the southern Aegean Sea over the last 48000 years. Palaeogeography Palaeoclimatology Palaeoecology 220, 311-332.

Geraga, M., Mylona, G., Tsaila-Monopoli, St., Papatheodorou, G., Ferentinos, G. 2008. Northeastern Ionian Sea: palaeoceanographic variability over the last 22 ka. Journal of Marine Systems 74, 623-638.

Geraga, M., Ioakim, Chr., Lykousis, V., Tsaila Monopolis, St, Mylona, G., 2010. The high resolution palaeoclimatic and palaeoceanographic history of the last 24,000 years in the central Aegean Sea, Greece. Palaeogeography Palaeoclimatology Palaeoecology 287, 101-115.

Gogou, A., Bouloubassi, I., Lykousis, V., Arnaboldi, M., Gaitani, P., Meyers, P.A., 2007 Organic geochemical evidence of abrupt late glacial-Holocene climate changes in the North Aegean Sea. Palaeogeography Palaeoclimatology Palaeoecology 256, 1-20.

Goudeau, M.-L.S., Reichart, G.-J., Wit, J.C., de Nooijer, L.J., Grauel, A.-L., Bernasconi, S.M., de Lange, G.J., 2015. Seasonality variations in the Centra Mediterranean during climate change events in the Late Holocene. Palaeogeography Palaeoclimatology Palaeoecology 418, 304-318.

Hammer, Ø., Harper, D.A.T., Ryan, P.D., 2001. Past: paleontological Statistics software package for education and data analysis. Palaeontologia Electronica 4 (4), 9 pp.

Hayes, A., Rohling, E.J., De Rijk, S., Kroon, D., Zachariasse, W.J., 1999. Mediterranean planktic foraminiferal faunas during the last glacial cycle. Marine Geology 153, 239-252.

Hemleben, C., Spindler, M., Anderson, O.R., 1989. Modern Planktic Foraminifera. Springer, New York, pp. 1-363.

Ignatiades, L., Psarra, S., Zervakis, V., Pagou, K., Souvermezoglou, E., Assimakopoulou, G., Gotsis-Skretas, O., 2002. Phytoplankton size-based dynamics in the Aegean Sea (Eastern Mediterranean). Journal of Marine Systems $36,11-28$.

Jorissen, F.J., Asioli, A., Borsetti, A.M., Capotondi, L., de Visser, J.P., Hilgen, F.J. Rohling, E.J., van der Borg, K., Vergnaud Grazzini, C., Zachariasse, W., 1993. Late Quaternary central Mediterranean biochronology. Marine Micropaleontology 21, 169-189.

Jung, S.J.A., Davies, G.R., Ganssen, G.M., Kroom, D., 2004. Stepwise Holocene aridification in NE Africa deduced from dust-borne radiogenic isotope records. Earth and Planetary Sciences Letters 7031, 1-11.

Karageorgis, A., Kanellopoulos, T.D., Mavromatis, V., Anagnostou, C.L. Koutsopoulou, E., Schmidt, M., Pavlopoulos, K., Tripsanas, E.K., Hallberg, R.O. 2012. Authigenic carbonate mineral formation in the Pagassitikos palaeolake during the latest Pleistocene, central Greece. Geo-Marine Letters. http:// dx.doi.org/10.1007/s00367-012-0306-y.

Kontakiotis, 2012. Palaeoceanographic and Palaeoclimatic Study of Eastern Mediterranean During Late Quaternary, Based on Planktonic Foraminiferal Assemblages (PhD thesis). National and Kapodistrian University of Athens, Greece pp. 1-247 (in Greek, with English extended abstract).

Kontakiotis, G., Antonarakou, A., Triantaphyllou, M.V., Mortyn, P.G., Bouloubassi, I, Gogou, A., Katsouras, G., Dermitzakis, M., Lykousis, V., Martínez-Botí, M.À. 2009. Planktonic foraminiferal $\mathrm{Mg} / \mathrm{Ca}$ as a proxy for paleoceanographic reconstruction during deposition of Holocene S1 sapropel in Aegean Sea. In: Proceedings of $9^{\text {th }}$ Symposium on Oceanography and Fishery, vol. 1, pp. 73-78.

Kontakiotis, G., Mortyn, P.G., Antonarakou, A., Martínez-Botí, M.À., Triantaphyllou, M.V., 2011. Field-based validation of a diagenetic effect on G. ruber $\mathrm{Mg} / \mathrm{Ca}$ paleothermometry: core top results from the Aegean Sea (eastern Mediterranean). Geochemistry Geophysics Geosystems 12 (9), Q09004.

Kontakiotis, G., Antonarakou, A., Zachariasse, W.J., 2013. Late Quaternary palaeoenvironmental changes in the Aegean Sea: interrelations and interactions between north and south Aegean Sea. Bulletin, Geological Society of Greece 47, 167.

Kotthoff, U., Pross, J., Müller, U.C., Peyron, O., Schmiedl, G., Schulz, H., Bordon, A. 2008. Climate dynamics in the borderlands of the Aegean Sea during formation of sapropel 1 deduced from a marine pollen record. Quaternary Science Reviews $27,832-845$

Kotthoff, U., Koutsodendris, A., Pross, J., Schmiedl, G., Bornemann, A., Kaul, C., Marino, G., Peyron, O., Schiebel, R., 2011. Impact of Lateglacial cold events on the northern Aegean region reconstructed from marine and terrestrial proxy data. Journal of Quaternary Science 26, 86-96.

Kouli, K., Gogou, A., Bouloubassi, I., Triantaphyllou, M.V., Ioakim, Chr., Katsouras, G., Roussakis, G., Lykousis, V., 2012. Late postglacial paleoenvironmental change in the northeastern Mediterranean region: combined palynological and molecular biomarker evidence. Quaternary International 261, 118-127.

Kucera, M., Weinelt, Mara, Kiefer, T., Pflaumann, U., Hayes, A., Weinelt, Martin, Chen, M.-T., Mix, A.C., Barrows, T.T., Cortijo, E., Duprat, J., Juggins, S. Waelbroeck, C., 2005. Reconstruction of the glacial Atlantic and Pacific seasurface temperatures from assemblages of planktonic foraminifera: multitechnique approach based on geographically constrained calibration datasets. Quaternary Science Reviews 24, 7-9. 
Kuhnt, T., Schmiedl, G., Ehrmann, W., Hamann, Y., Hemleben, C., 2007. Deep-sea ecosystem variability of the Aegean Sea during the past $22 \mathrm{kyr}$ as revealed by benthic foraminifera. Marine Micropaleontology 64, 141-162.

Kutzbach, J.E., Guetter, P.J., 1986. The influence of changing orbital parameters and surface boundary conditions on climate simulations for the last 18000 years. Journal of Atmospheric Sciences 43, 1726-1759.

Lambeck, K., Purcell, A., 2005. Sea-level change in the Mediterranean Sea since the LGM: model predictions for tectonically stable areas. Quaternary Science Reviews 24, 1969-1988.

Laskar, J., Robutel, P., Joutel, F., Gastineau, M., Correia, A.C.M., Levrard, B., 2004 A long-term numerical solution for the insolation quantities of the Earth. Astronomy and Astrophysics 428, 261-285.

Lourens, L.J., Hilgen, F.J., Gudjonsson, L., Zachariasse, W.J., 1994. Late Pliocene to Early Pleistocene astronomically forced sea surface productivity and temperature variations in the Mediterranean. In: Lourens, L.J. (Ed.), Astronomical Forcing of Mediterranean Climate During the Last 5.3 Million Years. Universiteit Utrecht, pp. 37-58.

Lykousis, V., 2001. Subaqueous bedforms on the Cyclades Plateau (NE Mediterranean)-evidence of Cretan Deep Water formation. Continental Shelf Research 21, 495-507.

Lykousis, V., Chronis, G., Tselepides, A., Price, N.B., Theocharis, A., Siokou-Fragou, I., van Wambeke, F., Danovaro, R., Stavrakakis, S., Duineveld, G., Georgopoulos, D. Ignatiades, L., Souvermezoglou, A., Voutsinou-Taliadouri, F., 2002. Major outputs of the recent multidisciplinary biogeochemical researches undertaken in the Aegean Sea. Journal of Marine Systems 33-34, 313-334.

Marino, G., Rohling, E.J., Rijpstra, W.I., Sangiorgi, F., Schouten, S., Sinninghe Damsté, J.S., 2007. The Aegean Sea as driver of hydrographic and ecological changes in the eastern Mediterranean. Geology 35, 675-678.

Marino, G., Rohling, E.J., Sangiorgi, F., Hayes, A., Casford, J.L., Lotter, A.F., Kucera, M. Brinkhuis, H., 2009. Early and middle Holocene in the Aegean Sea: interplay between high and low latitude climate variability. Quaternary Science Reviews 28, 3246-3262.

Mayewski, P.A., Rohling, E., Stager, C.J., Karlen, W., Maasch, K.A., Meeker, L.D. Meyerson, E.A. Gasse, F. van Kreveld, S., Holmgren, K., Lee-Thorp, J. Rosqvist, G., Rack, F., Staubwasser, M., Schneider, R.R., Steig, E., 2004. Holocene climate variability. Quaternary Research 62, 243-255.

Mazumder, A., Khare, N., Govil, P., 2009. Cosmopolitanism of the planktic foraminiferal species Globigerinita glutinata - a testimony by Q-mode cluster analysis. International Journal of Geology 1 (3), 1-7.

Negri, A., Capotondi, L., Keller, J., 1999. Calcareous nannofossils and planktic foraminifera distribution patterns in Late Quaternary-Holocene sapropel of the Ionian Sea. Marine Geology 157, 89-103.

Papanikolaou, D., Alexandri, M., Nomikou, P., Ballas, D., 2002. Morphotectonic structure of the North Aegean Basin based on swath bathymetry. Marine Geology 190, 465-492.

Pavlopoulos, K., Kapsimalis, V., Theodorakopoulou, K., Panagiotopoulos, I.P., 2011 Vertical displacement trends in the Aegean coastal zone (NE Mediterranean) during the Holocene assessed by geoarchaeological data. Holocene 22, $717-728$.

Poulos, S.E., 2009. Origin and distribution of theterrigenous component of the unconsolidated surface sediment of the Aegean floor: a synthesis. Continental Shelf Research 29, 2045-2060.

Poulos, S.E., Drakopoulos, P.G., Collins, M.B., 1997. Seasonal variability in sea surface oceanographic conditions in the Aegean Sea (Eastern Mediterranean): an overview. Journal of Marine Systems 13, 225-244.

Pujol, C., Vergnaud-Grazzini, C., 1995. Distribution patterns of live planktic foraminifers as related to regional hydrography and productive systems of the Mediterranean Sea. Marine Micropaleontology 25, 187-217.

Reiss, Z., Halitz, E., Boaz, L., 2000. Late-Holocene foraminifera from the SE Levantine Basin. Israeli Journal of Earth Science 48, 1-27.

Roether, W., Manca, B.B., Klein, B., Bregant, D., Georgopulos, D., Beitzel, V. Kovacevic, V., Luchetta, A., 1996. Recent changes in the Eastern Mediterranean deep water. Science 271, 333-335.

Rohling, E.J., 1994. Review and new aspects concerning the formation of Mediterranean sapropels. Marine Geology 122, 1-28.

Rohling, E.J., Gieskes, W.W.C., 1989. Late Quaternary changes in Mediterranean Intermediate Water density and formation rate. Paleoceanography 4, 531-545.

Rohling, E.J., Jorissen, F.J., Vergnaud-Grazzini, C., Zachariasse, W.J., 1993. Northern Levantine and Adriatic Quaternary planktic foraminifera: reconstruction of paleoenvironmental gradients. Marine Micropaleontology 21, 191-218.

Rohling, E.J., Den Dulk, M., Pujol, C., Vergnaud-Grazzini, C., 1995. Abrupt hydrographic change in the Alboran Sea (western Mediterranean) around 8000 yrs BP. Deep Sea Research 42, 1609-1619.

Rohling, E.J., Jorissen, F.J., De Stigter, H.C., 1997. 200 year interruption of Holocene sapropel formation in the Adriatic Sea. Journal of Micropaleontology 16, 97-108.

Rohling, E.J., Mayewski, P.A., Abu-Zied, R.H., Casford, J.S.L., Hayes, A., 2002. Holocene atmosphere-ocean interactions: records from Greenland and the Aegean Sea. Climate Dynamics 18, 587-593.
Rossignol-Strick, M., 1983. African monsoon, an immediate climate response to orbital insolation. Nature 304, 46-49.

Roussakis, G., Karageorgis, A.P., Conispoliatis, N., Lykousis, V., 2004. Last glacialHolocene sediment sequences in N. Aegean basins: structure, accumulation rates and clay mineral distribution. Geo-Marine Letters 24, 97-111.

Sbaffi, L., Wezel, F.C., Curzi, G., Zoppi, U., 2004. Millennial to centennial-scale palaeoclimatic variations during Termination I and the Holocene in the central Mediterranean Sea. Global and Planetary Change 40, 201-217.

Schiebel, R., Hemleben, Ch., 2000. Interannual variability of planktic foraminiferal populations and test flux in the eastern North Atlantic Ocean (JGOFS). Deep-Sea Research II 47 (9-11), 1809-1852.

Schiebel, R., Waniek, J., Bork, M., Hemleben, Ch., 2001. Planktic foraminiferal production stimulated by chlorophyll redistribution and entrainment of nutrients. Deep-Sea Research I 48, 721-740.

Sperling, M., Schmiedl, G., Hemleben, Ch., Emeis, K.C., Erlenkeuser, H., Grootes, P.M., 2003. Black Sea impact on the formation of eastern Mediterranean sapropel S1? Evidence from the Marmara Sea. Palaeogeography Palaeoclimatology Palaeoecology 190, 9-21.

Spero, H.J., Mielke, K.M., Kalve, E.M., Lea, D.W., Pak, D.K., 2003. Multispecies approach to reconstructing eastern equatorial Pacific thermocline hydrography during the past $360 \mathrm{kyr}$. Paleoceanography 18 (1), 1022. http://dx.doi.org/ 10.1029/2002PA000814.

Stanford, J.D., Hemingway, R., Rohling, E.J., Challenor, P.G., Medina-Elizalde, M., Lester, A.J., 2011. Sea-level probability for the last deglaciation: a statistical analysis of far-field records. Global and Planetary Change 79, 193-203.

Theocharis, A., Balopoulos, E., Kioroglou, S., Kontoyiannis, H., Iona, A., 1999. A synthesis of the circulation and hydrography of the South Aegean Sea and the Straits of the Cretan Arc (March 1994-January 1995). Progress in Oceanography 44, 469-509.

Thunell, R., Sautter, L.R., 1992. Planktonic foraminiferal faunal and stable isotopic indices of upwelling: a sediment trap study in the San Pedro basin, Southern California Bight. In: Summerhayes, C.P., Prell, W.L., Emeis, K.C. (Eds.), Upwelling Systems: Evolution Since the Early Miocene. Geological Society Special Publication, pp. 77-91.

Triantaphyllou, M.V., Antonarakou, A., Kouli, K., Dimiza, M., Kontakiotis, G., Ziveri, P., Mortyn, G., Lykousis, V., Dermitzakis, M.D., 2007. Plankton ecostratigraphy and pollen assemblage zones over the last 14.000 years in SE Aegean Sea (core NS14). Bulletin, Geological Society of Greece 40, 209-224.

Triantaphyllou, M.V., Antonarakou, A., Kouli, K., Dimiza, M., Kontakiotis, G., Papanikolaou, M.D., Ziveri, P., Mortyn, P.G., Lianou, V., Lykousis, V., Dermitzakis, M.D., 2009a. Late Glacial-Holocene ecostratigraphy of the southeastern Aegean Sea, based on plankton and pollen assemblages. Geo-Marine Letters 29 (4), 249-267.

Triantaphyllou, M.V., Ziveri, P., Gogou, A., Marino, G., Lykousis, V., Bouloubassi, I. Emeis, K.-C., Kouli, K., Dimiza, M., Rosell-Melé, A., Papanikolaou, M. Katsouras, G., Nunez, N., 2009b. Late Glacial-Holocene climate variability at the south-eastern margin of the Aegean Sea. Marine Geology 266, 182-197.

Triantaphyllou, M.V., Antonarakou, A., Dimiza, M., Anagnostou, Ch, 2010. Calcareous nannofossil and planktonic foraminiferal distributional patterns during deposition of sapropels S6, S5 and S1 in the Libyan Sea (Eastern Mediterranean). Geo-Marine Letters 30 (1) 1-13.

Triantaphyllou, M.V., Gogou, A., Bouloubassi, I., Dimiza, M., Kouli, K., Rousakis, G., Kotthoff, U., Emeis, K.-C., Papanikolaou, M., Athanasiou, M., Parinos, C., Ioakim, C., Lykousis, V., 2013. Evidence for a warm and humid Mid-Holocene episode in the Aegean and northern Levantine Seas (Greece, NE Mediterranean). Regional Environmental Change. http://dx.doi.org/10.1007/s10113-013-0495-6.

Vergnaud Grazzini, C., Ryan, W.B.F., Cita, M.B., 1977. Stable isotopic fractionation, climatic change and episodic stagnation in the eastern Mediterranean during the Late Quaternary. Marine Micropaleontology 2, 353-370.

Wilke, I., Meggers, H., Bickert, T., 2009. Depth habitats and seasonal distributions of recent planktic foraminifers in the Canary Islands region $\left(29^{\circ} \mathrm{N}\right)$ based on oxygen isotopes. Deep Sea Research, Part A 56 (1), 89-106.

Wit, J.C., Reichart, G.J., Jung, S.J.A., Kroon, D., 2010. Approaches to unravel seasonality in sea surface temperatures using paired single specimen foraminiferal $\delta^{18} \mathrm{O}$ and $\mathrm{Mg} / \mathrm{Ca}$ analyses. Paleoceanography 25, 1-15.

Zachariasse, W.J., Jorissen, F.J., Perissoratis, C., Rohling, E.J., Tsapralis, V., 1997. Late Quanternary foramineteral changes and the nature of sapropel S1 in Skopelos Basin. In: 5th Hell. Symp. Oceanogr. Fish., NCMR Athens, Proceedings 1, pp. 391-394.

Žarić, S., Donner, B., Fischer, G., Mulitza, S., Wefer, G., 2005. Sensitivity of planktic foraminifera to sea surface temperature and export production as derived from sediment trap data. Marine Micropaleontology 55, 75-105.

Zervakis, V., Georgopoulos, D., Drakopoulos, P.G., 2000. The role of the North Aegean in triggering the recent Eastern Mediterranean climatic changes. Journal of Geophysical Research 105, 26103-26116.

Zervakis, V., Karageorgis, A.P., Kontoyiannis, H., Papadopoulos, V., Lykousis, V., 2005. Hydrology, circulation and distribution of particulate matter in Thermaikos Gulf (NW Aegean Sea), during September 2001-October 2001 and February 2002. Continental Shelf Research 25, 2332-2349. 